Article

\title{
Exploring the Emergence of Innovative Multi-Actor Collaborations toward a Progressive Urban Regime in Madrid (2015-2019)
}

\author{
Clara Medina-García ${ }^{1,2, *(\mathbb{D})}$, Rosa de la Fuente ${ }^{2}$ (D) and Pieter Van den Broeck $^{1}$ (D) \\ 1 Department of Architecture, KU Leuven, 3001 Leuven, Belgium; pieter.vandenbroeck@kuleuven.be \\ 2 Department of Political History, Theories and Geography, Faculty of Political Sciences and Sociology, \\ Complutense University of Madrid (UCM), Campus de Somosaguas, 28223 Pozuelo de Alarcón, Spain; \\ rdelafuente@cps.ucm.es \\ * Correspondence: clara.medinagarcia@kuleuven.be
}

Citation: Medina-García, C.;

de la Fuente, R.; Van den Broeck, P.

Exploring the Emergence of

Innovative Multi-Actor

Collaborations toward a Progressive

Urban Regime in Madrid (2015-2019).

Sustainability 2021, 13, 415. https://

doi.org/10.3390/su13010415

Received: 15 November 2020

Accepted: 29 December 2020

Published: 5 January 2021

Publisher's Note: MDPI stays neutral with regard to jurisdictional clai$\mathrm{ms}$ in published maps and institutional affiliations.

Copyright: $(2021$ by the authors. Licensee MDPI, Basel, Switzerland. This article is an open access article distributed under the terms and conditions of the Creative Commons Attribution (CC BY) license (https:// creativecommons.org/licenses/by/ $4.0 /)$.

\begin{abstract}
For the last decade, urban actors around the globe have been struggling to adapt to a postcrisis and austerity context through increasing social mobilization and experimentation, calling for an urban democracy renewal and challenging established neoliberal urban regimes and governance systems. This has triggered social innovations, in which novel collaborative formulas have been envisioned and implemented. In particular, civil-public collaborations (CPCs) have come to the fore as an empowering alternative to the well-established private-public partnerships (PPP). This article examines the conditions of possibility, enabling mechanisms and constraints for the emergence of innovative multi-actor collaborations (IMACs). For this aim, we developed a three-fold analytical framework combining social innovation, public governance, and urban regime theory. We applied this framework to the case of the so-called "government of change" in Madrid between 2015 and 2019. After exploring the pre-2015 context, the institutional innovations implemented once Ahora Madrid accessed the local government, and the post-2019 context, it points to the preconditions that allowed experimentation with IMAC, identifies the institutional mechanisms and governance innovations that support their emergence, and assesses to what extent and how power to act was created and used to accomplish urban regime change.
\end{abstract}

Keywords: civil-public collaboration; democratic innovation; government of change; governance; Madrid; multi-actor collaboration; public policy; social innovation; urban regime change

\section{Introduction}

For the last decade, urban actors have been struggling to adapt to a post-crisis and austerity context through increasing social mobilization and experimentation, calling for an urban democracy renewal and challenging established neoliberal urban regimes and governance systems [1-3]. At the same time, social innovation (SI) has kept raising interest in contemporary socio-political and academic debates about the quest for an alternative sustainable development paradigm to tackle the present and future sociopolitical, ecological, and economic challenges of modern societies [4]. The promotion of SI by governments and international organizations like the United Nations and the European Union since the 1990s has inspired programs for sustainable urban regeneration and to fight social exclusion and poverty [5]. In parallel, SI strategies have been sought by local administrations pressed to "do more with less and do better" [5] and to modernize the welfare state by collaborating with other actors in mixed networks [6] as a consequence of resource constraints and increasing inequalities. In the meantime, traditional grassroots movements and new urban activists (NUA) [7] have started organizing and taking action themselves [8] to find creative solutions to the provision of individual and collective needs that are not being fulfilled by weakened administrations or the market [9]. Not only 
did they innovate in social relations and demand redistribution mechanisms, but they also aimed at increasing the citizens' rights and power to decide and affect politics [8], especially at the local level.

In Spain, the post-crisis mobilization articulated and spread from the $15 \mathrm{M}$ movement, and surged on 15 May 2011 with demonstrations and occupations in the main squares of the country in protest to the austerity measures imposed by the national government [10]. Soon, mobilizations transformed into neighborhood citizen assemblies and triggered the strengthening and creation of civil organizations. From these assemblies, independent parties emerged that managed to win the local elections of May 2015, constituting the so-called "governments of change" in several Spanish cities. Such was the case in Madrid, where the independent political platform Ahora Madrid (Now Madrid) has opened the door for translating at the institutional level social innovations that had been experimented in the previous years in the civil sphere or within the cracks of the institutional local framework [11]. Following the principles of New Municipalism [12], this approach challenged the post-political governance system $[13,14]$ and unlocked new possibilities for multi-actor collaboration (MAC). A keen interest was set in boosting civil-public collaboration (CPC), the establishment of new alliances to gain power to act [15] around progressive agenda issues, and investigating new ways to share resources and empower urban actors that had been losing political capacity of influence in the production of the city.

The pursuit of such objectives from the local administration has implied a change in the nature of SI, which stopped being performed as a bottom-up phenomenon. Instead, $\mathrm{SI}$, in these transformations, is happening through the envisioning and implementation of more or less formalized multi-actor collaborations (MACs) and networks, gathering individual and collective civil actors, public agencies, knowledge institutions, and private actors [8] as a new governance mechanism to share efforts and resources to address complex urban challenges in the city [16,17].

In this article, we argue that ongoing experimentations with multi-actor collaborations addressing complex urban challenges illustrate empirical examples of social innovation seeking democratic innovation triggered from or participated in by the local administrations and contribute to change toward progressive urban regimes. Such a regime is characterized by a strong commitment of the middle classes and a clear objective of achieving more equal and sustainable urban development $[15,18,19]$. Change toward such a regime implies the construction of a new governance system and the redesign of social and public collaborative networks gaining power to act toward progressive agendas. Some scholars have already made efforts to connect socially innovative initiatives with administrations through concepts like "bottom-linked" and "multi-level governance" [20-22], and Kazepov et al. [23] evidenced, in their research about welfare and poverty, that SI is not solely a bottom-up practice. However, most empirical research under the frame of SI (see among others [24-28]) tends to be conducted from the perspective of civil and grassroots initiatives $[29,30]$. From this approach, local state administrations continue to be studied from their role as allies or obstacles for bottom-up initiatives. As a result, the potential of MAC to drive social innovation and contribute to regime change remains undertheorized.

Thus, this article examines the conditions of possibility, enabling mechanisms, and constraints for the emergence of MAC as social innovation interacting with urban regime change, conceptualized as innovative multi-actor collaborations (IMACs). Specifically, it addresses the following research questions: (1) Why and how do IMACs emerge?; (2) Which tools and mechanisms implemented (by the local administration) support IMACs?; and (3) How do IMACs contribute to governance innovation and urban regime change and vice-versa?

To answer these questions, in Section 2, we developed a three-fold analytical framework combining SI, public governance, and urban regime change theories. This framework was applied to analyze the innovations implemented by the "government of change" in Madrid between 2015 and 2019. Section 3 presents the case study and methodology used 
for its analysis, Section 4 describes the results of the analysis, and conclusions are drawn in Section 5.

\section{Social Innovation, Public Governance, and Urban Regime Change: Developing a Three-Fold Analytical Framework}

Theoretical advancements from the fields of social innovation, public governance, and urban regime theory are presented and combined in this section to develop an interdisciplinary analytical framework that allowed us to characterize innovative multi-actor collaboration (IMAC), study the conditions of possibility and policy tools that enable their emergence and functioning, and assess their impact on changing prevailing urban governance and regimes and vice-versa. In the development of this framework, we complement SI theory with approaches that bring in the perspective from (local) administrations, and link the emergence of IMAC to debates on democratic innovation and urban regime change.

\subsection{Innovative Multi-Actor Collaboration (IMAC) and Social Innovation}

Our analytical framework starts from a review of how existing literature on SI relates (or not) to the emergence and functioning of IMAC. According to Moulaert and MacCallum [5], SI theory is historically divided in two main academic trends.

On one hand, the Anglo-American approach, from the fields of economics, business innovation, and organizational management, defines SI as "new ideas (products, services, and models) that simultaneously meet social needs more effectively than alternatives, and create new social relations or collaborations" [31]. The focus is set on entrepreneurship for individual empowerment and business efficacy and efficiency in both private organizations and European programs [31,32] (see also Druker and University of Stanford). It is under this frame that administrations, especially at the local level, have been pressed to "do more with less and do better" [5] and to modernize the welfare state by collaborating with other actors in mixed networks [6] as a consequence to resource constraints. From such an approach, SI is encouraged to achieve economic efficiency, but not due to a concern about renewing democracy.

On the other hand, the so-called Euro-Canadian approach was developed from the social sciences including sociology, political sciences, and urban economics [33-36], and has expanded into territorial studies including urban and development studies, spatial planning, and urbanism [37-42]. In opposition to the previous approach, scholars in this strand agree that SI is about empowering marginalized citizens and driving collective action by changing power relations to address collective needs, goals, or challenges that the state or market are failing to solve $[5,43,44]$. Therefore, this strand is tightly linked with the study of emancipatory and resistance movements and concepts like participation, democratic governance, social capital, and networks, etc. Not only is SI understood as "new ways of creating social change" [44], but it is also recognized for its potential to drive socio-political transformations [42] at three levels: (1) challenging power asymmetries in urban governance; (2) introducing institutional changes in governance systems; and (3) bringing about alternative development models to prevailing neoliberal trajectories [45]. From this approach, SI is regarded as a tool to redefine democracy as a collective production process and attention has been paid to "issues of path-dependency and multi-scalar governance relations, as limitations to, sites of, and concentrations of resources for social change" [46].

In our research, we embraced the latter approach to SI, which stresses institutional and power transformations, to investigate MAC as SI that manages to "open windows for more democratic dialogue, collective cross-learning, and shared visions with citizens and civic associations" [13]. From this approach, we undertook the socio-institutional analysis of socially innovative processes [47], which requires paying attention to both the actors that are involved and the institutional tools and mechanisms that allow the creation of what Healey [48] describes as "shared spaces", paying attention to their specific temporal, socio-economic, institutional, political, and cultural context $[37,49]$. From such a perspective, governance is studied as the different systems for coordination among actors 
and the redefinition of power relations between civil and state agents along and as a result of the SI process [34].

However, the potential of MAC to drive social innovation remains undertheorized. For instance, Lukesch et al. [50] (p. 6) argued that "Social innovation initiatives may either challenge the political-institutional fabric or act on invitation, bringing forth the pilot projects and practice examples-called "niches" in transition theory-that policy makers need to put forward and expand their agendas". Such a statement disregards the alternative of SI, which is driven by more horizontal MACs that co-develop agenda issues, support (pilot) projects in relation to common concerns of the different urban actors involved, and have varying degrees of formalization and contribution of the different actors along time. In this article, we conceptualize such processes as innovative multi-actor collaborations (IMACs).

The enabling and functioning mechanisms and policies that trigger and allow such IMACs to emerge are also undertheorized. Both theoretical elaborations and empirical research under this frame of SI (see among others [27-31]) tend to be conducted from the point of view of civil movements and bottom-up initiatives. However, the literature on social movements have already revealed the great difficulty faced by grass-root initiatives to accumulate power, let new actors in, and eventually change dominant governance cultures [47]. A similar constraint is attributed to SI at the community or local level, encountering difficulties in working upstream and changing social and power relations at higher societal and governance scales. Consequently, several authors have stressed the need to redefine socio-public relations [51] and find ways to institutionalize and increase the governance capacity of socially innovative initiatives, which can be achieved, for instance, with bottom-linked and multi-level governance structures [6,20-22,51]. Moulaert et al. [30] defined bottom-linked governance as "new forms of democratic governance collaboratively built between initiatives and activists, their scalarly dynamic networks and state institutions and agencies". Still, further research along this line keeps focusing on administrations as allies or obstacles for locally-based bottom-up initiatives. Only incipient elaborations around "hybrid governance" $[52,53]$ start addressing the complex processes within SI from a multi-actor perspective, focusing on the combination and coexistence of market, hierarchy, network, and solidarity governance logics [54,55] in SI processes.

\subsection{IMAC, Democratic Innovation, and Public Governance Transformation}

A parallel debate on governance innovation is on-going in the field of public administration among others [56-64]. It considers emerging public governance paradigms and emanates from a broader discussion on how new "participatory imaginaries of democracy" can challenge current democratic recession [3]. In the following paragraphs, we explore debates and concepts related to democratic and governance innovation that help us complement the bottom-linked governance concept used in SI theory.

In his book, de Souza Briggs [65] presented an analysis of the evolution of different understandings of democracy, highlighting two opposing approaches: contest democracy and deliberative democracy. The former is related to elite control and focuses on conflicts of interests among urban actors and on conflict resolution, while the latter sees democracy as a "powerful tool for deliberation", a collective process that seeks to reach understanding among urban actors. However, he argues that "real democracies", as opposed to idealized ones, contain both strategic (contested) and learning oriented (deliberative) elements, an understanding similar to the notion of hybrid governance. Thus, he introduces a third approach that defines democracy as "a recipe for structuring the participation of stakeholders in solving problems that confront them collectively in a way that (1) makes significant decisions as accessible and inclusive as possible and (2) avoids patterns of domination, subject to the aim of (3) producing outcomes that are recognized as promoting legitimate interests and values" [65] (p. 312). Such a conceptualization in the framework of the current landscape of wicked urban problems already introduces an incipient characterization of 
IMACs as mechanisms that are able to produce legitimacy and productive capacity [17], bypassing the current democratic malaise and the questioning of administration legitimacy.

Complementarily, Elstub and Escobar [66] described how current democratic innovations are being informed by participatory and deliberative democracy models as a complement or improvement to representative democracy, which is increasingly criticized for its elitism. They characterize current democratic innovations as "a compromise between the aspirations of participatory democracy from the 1960s and the revived pragmatism regarding current challenges on public governance and the need for new modes of collective action" [66] (p. 18). The aforementioned debates about democratic models inform further discussions within the field of public administration on public governance and bureaucracy. These aim to understand (1) the motives, philosophies, and strategies followed by (local) administrations in order to address pressing urban issues; (2) the structural framework in which (democratic) innovations triggered or participated by public administrations are being developed; and (3) the changing relation between state and civil actors. This field pays further attention to the development and co-existence of public governance paradigms, understood as "the underlying policies, strategies, programs and institutional templates that govern the particular manner in which the public sector is structured, functioning and operating" [67] (p. 2). Hence, changes in governance occur responding to critical diagnosis of the past and trying to address present and future challenges of the public sector that previous paradigms are unable to cope with (ibid.).

This is precisely how New Public Management (NPM) state reforms spread in the 1980s to modernize the increasingly bureaucratized welfare state, which was criticized for its rigidity and lack of efficiency and efficacy in service provision $[59,67]$. These reforms incentivized the integration of principles borrowed from market and managerial logics in the public sector, pushing toward decentralization, deregulation, liberalization, competition, and privatization, which led to the retrenchment of the state in favor of private actors $[59,67,68]$. NPM has been linked to the development of neoliberal principles [67] and the austerity measures promoted around the globe to tackle the effects of the global economic crisis of 2008 [6].

NPM was soon contested. First, it triggered the development of New Webberian State ideals that recognized the need to recover principles linked to bureaucracies that were being lost such as impartiality, equity, transparency, and accountability $[67,68]$. NPM was also criticized for its elitist and restrictive representation and participation models [48]. These were blamed for broadening the differences between "them" in authoritative roles and "us" as citizens, only considered as consumers of services [66], and increasing dissatisfaction and mistrust from civil society toward public administrations $[48,69]$. Such tensions and critiques led to specific multi-actor partnerships, especially in the fields of spatial planning and urban policy [48], and the development and proliferation of interactive forms of governance under the umbrella of New Governance paradigms [16,59,67]. This counter current argues that current welfare states are no longer capable of providing the required problem-solving, delivery, and coordination capacity required to face the increasing complex urban agendas [48] and integrates citizens and other affected urban actors through problem-solving networks and partnerships [16,67].

Specifically, Geissel [69] identified three broad categories of new participatory practices that are relevant for building our analytical framework in relation to the institutional innovations that have been set in place to facilitate IMAC: co-governance (also referred to as collaborative governance), deliberative procedures, and direct democracy. Collaborative governance, in its broader sense, is defined by Ansell and Gash [70] as "A governing arrangement where one or more public agencies directly engage non-state stakeholders in a collective decision-making process that is formal, consensus-oriented, and deliberative and that aims to make or implement public policy or manage public programs or assets". Its emergence is directly linked to the critiques against issues related to managerialism such as adversarialism and accountability as well as to answer to the growing complexity and interdependence of urban issues. Complementarily, as Healey [48] de- 
scribes, deliberative and network governance has emerged as a third alternative to elitist and self-organization approaches, keeping a collective approach toward decision-making as the latter, but recognizing that "civil society needs formal government in many ways". Deliberative practices can range from minimal deliberative information-exchanging events to longer and discussion-rich high-quality deliberative processes, and are normally used as consultative procedures to inform decisions made by decision-making bodies [69]. Network governance moves a step further and is expected to increase collective capacity to address wicked problems while enhancing democratic legitimacy and the effectiveness of decision-making processes and outcomes [71] by combining authority, empowerment, and flexibility [16]. Finally, direct democracy is linked to principles of participatory democracy, which seeks a structural social change in which "ordinary people are empowered to make political decisions directly for themselves in their everyday lives as well as in the broader political system" as described by Pateman (2012), cited in [72] (p. 40). Practices along this line include consultative or binding popular voting sessions on policies and rules [69].

Several authors have further analyzed the conditions for success in the implementation of these governance innovations, agreeing on the following three requirements that we integrated in our analytical framework. First, they stressed the importance of considering pre-conditions at different levels (macro, meso and micro) [16] and in regard to different aspects (power (im)balance, incentives to collaborate, and the pre-history of collaboration among urban actors) [70]. Second, they studied the appropriate institutional design that "sets the basic ground rules under which collaborations take place" [70] and the specific policy tools that enable institutional sites of exchange [48]. In this regard, more than exploring the conflict between the implementation of democratic innovations toward each of the participatory practices identified by Geissel [69] (i.e., collaborative governance, deliberative procedures, and direct democracy), we used this classification as helpful analytical categories to fine-tune the analysis of institutional designs supporting IMAC. Finally, they remind us of the importance of mobilizing mediating and facilitative leadership to assist the collaborative process when conflict arises and to ensure the empowerment of weaker actors [70].

These requirements are tightly connected with specific elaborations on the role of public administrations and administrators in IMACs. For instance, when McGuire and Agranoff [73] set networks vis-à-vis administrations in this new governance context, they observed that the role of state actors is shifting rather than shrinking, transforming into facilitators and co-operating partners. Additionally, public actors are not just "any other actor" in governance networks since they count as unique resources and capacities and remain the legitimate actor for passing policies and distributing power and responsibilities to other actors [73]. In addition, Sorensen and Torfing [16] stressed how the current role of public managers is not to "innovate by themselves", but to create and institutionalize arenas of collaboration for all affected actors to innovate together. This is what Jessop [22] refers to as the meta-governance role of government agencies when they (re)design the conditions of governance, organize dialogue, and re-balance power imbalances, mobilizing their distinctive sovereignty and capacities $[55,73]$.

\subsection{IMAC and Urban Regime Change}

IMAC as a democratic mechanism would be a new way to discuss, design, and implement urban policies to solve wicked problems. However, as Healey [48] underlined, such a mechanism would not only have an impact as an isolated initiative, but could also have a broader impact over time, deeply changing the political culture. In order to assess change in urban governance over time, we incorporated urban regime theory, and did so following Stone's [74] assumption that effective urban regime change comes about from cumulative alterations of "the playing field".

When analyzing an urban regime, Stone [15,19] identified four core elements: " $(1)$ a capacity to do something; (2) a set of actors who do it [ ... ]; (3) a relationship between the 
actors that enables them to work together; and (4) durability of the first three elements over some period of years." Furthermore, he stressed the importance of civic capacity, understood as the ability to establish new networks and coalitions of actors for specific purposes (the political agenda pursued) to drive political change, and so noticed that the main challenge in such a process is an organizational one [74]. The notion of civic capacity involves both a logic of actor mobilization and empowerment, changing political relations and access to influence, and the logic of effectiveness in collective problem-solving $[19,26]$. As such, both stable coalitions with broad support that legitimate agreements and pragmatic alliances that get things done are needed for building and expanding civic capacity [65].

Stone identified four types of urban regimes [18]: (1) the "caretaker" seeks to maintain the established order; (2) the "developmental" pursues economic growth; (3) the "opportunity expansion" aims at improving the living conditions of popular sectors of society; and (4) the middle-class progressive regimes, which focus "on such measures as environmental protection, historic preservation, affordable housing, the quality of design, affirmative action, and linkage funds for various social purposes" [19] (p. 19). Previous studies by Blanco $[35,71]$ applied urban regime theory to study governance networks in the context of Barcelona, and showed how they even changed inside the city and in relation to each policy domain. In that sense, Rosso and Scarnato [75] specifically studied the coalition of actors to change a specific policy domain, the tourist one, also in the case of the current urban regime change in Barcelona. Such research has already evolved from the study of coalitions of actors to resistance networks. In our analysis, we took the integration of urban regime theory a step further to analyze the potentiality of IMAC and SI to contribute to urban regime change toward progressive urban regimes, which are considered to require more civic participation and support [18]. With our research, we aim to identify if and under which circumstances this statement is true.

\subsection{Combining the Theories into a Three-Fold Analytical Framework}

All three theories explained pay attention to agency, institutions, and structure, yet bring complementarities to enrich the three-fold analytical framework that guides our analysis, as illustrated in Figure 1.

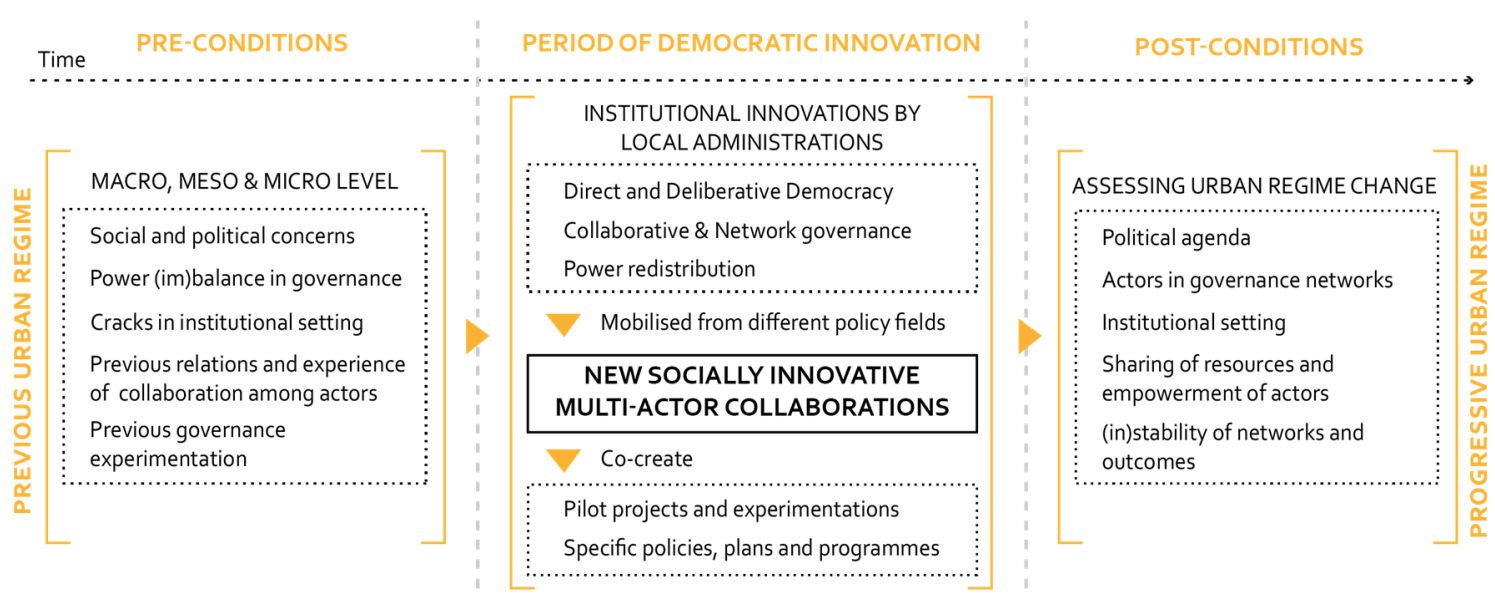

Figure 1. Analytical framework integrating input from social innovation, public governance, and urban regime change theories.

From the combination of all theories, we understand that the analysis shall, at least, take into account three temporal moments of the same socio-political and geographical unit of research: before the IMACs (the pre-conditions), during and along the development of the IMACs (including their institutional design), and the post-conditions (after their establishment or once the collaborations have ended). Each theory adds nuance on what to analyze in each of the stages. 
From SI, we integrated the socio-institutional analysis of IMAC, which involves studying the actors involved, together with the political, institutional, and organizational mechanisms mobilized to drive IMAC as well as attention not only to the temporal, but also to the spatial, socio-political context in which IMAC takes place. This approach also integrates the consideration of SI, and therefore of IMAC, both as a process and an outcome [51], understanding that not only do we need to analyze the democratic innovation pursued, but also the institutional pre-setting and processes that allow such innovation. Consequently, the framework requires the analysis of previous experimental governance practices, developed mainly within civil society or toward CPC in the interstices or "cracks" of dominating elite and technocratic forms of governance in the austerity context [76], that opened windows of opportunity for further experimentation and implementation of new institutional designs for urban governance by public administrations. The theories from the field of public administration, as discussed in the previous section [70], also enrich the analysis of the pre-conditions for IMAC, indicating conditions at different levels (macro, meso, and micro) [16] related to different aspects such as power (im)balance, incentives to collaborate, and the pre-history of collaboration of urban actors.

The categories of democratic and governance innovation are then brought in to enrich the understanding of the new institutional designs implemented by local administrations. Consequently, we studied the mechanisms implemented to enhance direct and deliberative democracy on the one hand, and collaborative and network governance on the other, as well as those aimed at re-balancing power relations among urban actors. We then investigated how such mechanisms are mobilized from specific policy fields to establish an IMAC integrating new urban actors in co-creation and policy-making processes and the specific outcomes of such IMAC processes.

The last section of the framework focuses on the post-conditions of IMAC, analyzing whether IMACs contributed to a change toward a progressive urban regime in the city and expanding the aspects already considered from a socio-institutional approach. The five categories studied to assess urban regime change were: (1) the political agenda pursued; (2) the actors involved in governance networks; (3) the institutional setting in which networks are set; (4) how resources are shared and mobilized to empower actors; and (5) the (in)stability of the multi-actor networks and their outcomes. These are useful to study change, and so able to relate SI with urban governance transformation.

\section{Materials and Methods: Application of the Analytical Framework in the Case Study of Madrid}

As Yin [77] describes, the case study methodology is the most appropriate to gain an in-depth understanding of an on-going phenomenon, and thus be able to answer the "how" and "why" questions addressed in this research. In this research we applied the analytical framework described in the previous section to the case study of Madrid during the "government of change" period (2015-2019) to analyze (if and) under which conditions an IMAC triggered by or participated by local administrations contributed to change toward a progressive urban regime and vice versa. The choice of this "critical case" [78] (p. 219) allowed us to identify specific characteristics of this phenomenon and contribute to deepening its general understanding, without aiming to be representative of all possible situations. The choice relies on our assumption that the specific conditions under which democratic and policy innovations were experimented with and implemented along the ruling period of Ahora Madrid following the principles of the New Municipalism [12], represent an example of mobilization against neoliberal economic and governance principles in which IMAC contributed to progressive urban regime change.

In our analysis, different data gathering techniques were combined. First, we revised previous research on the post-crisis social mobilization in Madrid and the emergence and evolution of Ahora Madrid. This enabled us to understand the pre-conditions of the "government of change" and the context of the emergence of initiatives for social and democratic innovation and Ahora Madrid as a coalition of political parties and other civil actors. This stage of the analysis of secondary data also included reviewing documents 
developed by the actors that had been innovating during that period, like those by the Observatorio Metropolitano or la Mesa Ciudadana. Further documental research continued during the analysis of the following stage and included a systematic analysis of the policies, strategies, and official documents and communications developed by Ahora Madrid between 2014 and 2020 in order to understand the framework of institutional innovation developed. The perspective from the local administration was complemented with the review of news and press articles and other secondary sources developed and shared by other actors involved in IMACs such as websites, project reports, and meetings minutes, for instance, from the Local Forums and the Mares Madrid project.

Second, documental research was combined with field research to better understand the actors involved and relations established, the process of implementation and development of social and democratic innovations, and the articulation between civic and institutional innovations. Fieldwork comprised participant observation conducted by two of the researchers between 2015 and 2020 in some of the initiatives studied (i.e., Foros Locales (Local Forums), Decide Madrid, and Mares Madrid) and at different events and conferences organized by the City Hall to present and debate the strategies that were being developed (i.e., the presentations of the Strategy for Social and Solidary Economy (SSE) and the Plan MAD-RE and the CONSULcon). Specifically, both researchers took a very active role within the Local Forum in the Arganzuela District, one of them being a member of the education working table and the Vice-President of such a Local Forum between 2016 and 2019, while the other researcher joined the urbanism working table within the same Forum between 2017 and 2020, taking up the role of coordinator since 2019. Such an active role and deep engagement in the ongoing initiatives and with the actors involved required continuous epistemological reflection and vigilance, which was facilitated by the involvement of the third researcher as an external controller of the fieldwork being conducted. The observations and informal conversations during participatory observation, with attendees in the initiatives, were complemented with a series of further conversations, discussions, and reflections with actors involved and ten semi-structured-interviews with public administrators, political representatives, and partners involved in Mares Madrid. Furthermore, three round tables were organized between 2018 and 2020 to discuss the process from a retrospective point of view with some members of Ahora Madrid that had joined the local government.

The data generated was gathered and analyzed in an incremental way through qualitative analysis, drawing on the three main categories included in our analytical framework as explained in the previous section: conditions of possibility for multi-actor collaboration, social innovation, and democratic innovation. This was achieved through the systematization of data in the field notebooks of the two researchers involved in fieldwork and the development of conceptual maps of the actors, institutional frameworks, and relations among these. During the research, as new policies and strategies were passed and our understanding of the processes increased, new connections and insights emerged that enriched the initial analysis and maps, such as the tables and figures included in Section 4. The analytical framework guided our characterization of the results explained in the following section and the discussion about the emergence, functioning, and implications of MAC in social innovation and urban regime change.

\section{Results}

In this section, we explain the results from our analysis of IMAC in Madrid organized along the three time periods and following the analytical categories explained above.

\subsection{Pre-2015 Contextualization: Tracing Back the Conditions of Possibility}

Our analysis of the pre-conditions for the democratic and governance experimentations that led to IMACs in the ruling period of Ahora Madrid between 2015 and 2019 was initiated in a previous research on the impact of civil movements in urban governance transformation [11]. In this regard, we identified three main socio-political and economic 
conditions of possibility. First, as explained in the introduction, the effects of the post-crisis austerity measures triggered the new surge of social mobilization around the $15 \mathrm{M}$ movement and collective experimentation to fight the effects of the crisis that reactivated civil networks [10]. In this process, New Urban Activists (NUA) emerged as new urban and political actors [7]. Second, incipient governance experimentation and multi-actor networks found a way to take advantage of "institutional cracks" under the umbrella of municipal innovation labs and specific administrative areas. These experimentations, led by civil organizations and pioneering public agencies and/or individual "champions" within the local administration, became vital experiments in researching and implementing new mechanisms for horizontal organization, assembly decision-making, citizen engagement, and transparency, which laid the basis for new institutional mechanisms and collaborations to be developed later by the local administration. Third, the development of municipalist counter-discourses against the neoliberal austerity measures in the post-crisis context fed the alternative independent political platform Ahora Madrid, which managed to enter local government and gain a new institutional power to act.

\subsubsection{Post-Crisis Mobilization Reacting to a Developmental Urban Regime}

The $15 \mathrm{M}$ mobilizations and subsequent civil activity spread in different Spanish cities in 2011 in reaction to the austerity measures that the national government had implemented after the global economic crisis $[10,27,79]$. These can be directly linked to other global "occupy" activist practices with a clear focus on the collective production of public space through the occupation of squares and publicly owned plots and buildings. However, from the analysis of their motivations and revindications, the $15 \mathrm{M}$ movement revealed a deeper socio-political conflict challenging the basis of the Spanish representative democratic system $[2,10]$. Not only did they aim at contesting the consequences of the crisis, but also the democratic deficit that was widely perceived (ibid.). There was a general understanding among new social movements that democratic changes were unlikely to happen in institutions unless they were already practiced daily in social organizations.

Specifically in the case of Madrid, these social claims reacted against a well-established developmental regime installed by the Partido Popular (People's party) (PP) [79,80], which had been ruling the capital city and its region for more than twenty years, aiming to turn Madrid into a global city [14,80-82]. Indeed, a hegemonic discourse had been built focused on economic and urban growth by means of privatizing services, establishing public-private partnerships, and developing large urban operations. In such a model, the party's conception regarding participation and collaboration with other actors can be considered as elitist, with restrictive and selective criteria to allow civil actors to contribute to urban governance $[14,82]$. When the economic crisis hit, Madrid was faced with huge debts, unfinished mega-projects, empty plots, lack of public infrastructure, and weakened social services [81,82]. It came as no surprise that social mobilization, related to the $15 \mathrm{M}$ movement in Madrid, not only reacted to the effects of austerity measures at the national level, but to very specific and pressing socio-economic and democratic issues at the local level.

\subsubsection{New Urban Activists and Post-Crisis Civil Experimentation in Madrid}

In such a context of social mobilization, Wallister $[7,79,83]$ identified the emergence of the "New Urban Activists" (NUA): "highly educated groups that use professional expertise for collaborative urban interventions in a context of social innovation". According to his research, NUA filled a void left by traditional members of social movements and NGOs as service and expertise providers. They completely transformed the performance of organizations with greater technical and network capacities. First, their professional profile including architects, economists, sociologists, designers, lawyers, etc. and their frequent affiliation in professional collectives like Paisaje Transversal, Vivero de Iniciativas Ciudanas (VIC), and Todo por la Praxis (TxP) increased the organizational capacity of civil action while accelerating a process of hybridization of roles, blurring the boundaries between ac- 
tivism, volunteering, and professional work. Second, NUA have contributed to the spread of new practices in civil action, like the use of information and communication technologies and the virtual space to democratize information with multidirectional, horizontal and real-time flows of information. They have also embraced the pro-commons philosophy and supported collective intelligence, enhancing learning processes through sharing individual and collective knowledge and experiences and the establishment of collaborative networks among projects and initiatives in which they participated. The emergence of new political actors is a very specific pre-condition in our case study to understand the emergence of claims and reactive SI $[81,84]$.

Additionally, members of more traditional urban grassroots organizations that had become the main (and almost only) interlocutor with public administrations such as neighborhood associations, were involved, together with individual citizens, in recreating social tissue in the neighborhoods during the crisis. From the many types of social initiatives developed after the $15 \mathrm{M}$, self-managed civic centers stood out as social co-productions of space and collaborative and network governance experimentations [83]. Esto es una Plaza, Patio Maravillas, and El Campo de la Cebada are some examples of such initiatives. They claimed the right to open and empty publicly owned plots and buildings for citizen management to tackle the lack of public space and equipment. In line with NUA's principles, these platforms did not work in isolation, but actively enhanced knowledge sharing, collective intelligence, networking, and combining their physical space and activities with active blogs and social media profiles [11]. In addition, many movements were organized in (inter)national networks [81] like the Red de Espacios Ciudadanos (Network of Citizen Spaces) and the Red de Huertos Urbanos (Network of Urban Gardens) [11].

\subsubsection{Municipal Innovation Labs and Institutional “Cracks" before 2015}

Despite the general reactive and hostile attitude of the local government in Madrid toward 15 M-related mobilizations and NUA intervention before 2015 [85], exceptional opportunities had arisen for socially innovative projects to thrive around specific topics, especially thanks to the Directorate of Culture [7,86]. In 2007, Medialab Prado and Intermediae Matadero were created as flagship innovation labs to position the city in the international cultural arena. These labs welcomed collaborative cultural projects and horizontal and transdisciplinary dialogue and interaction among creative and associative networks in the city. Together, they fostered and funded different NUA organizations as creative and artistic initiatives, opened their premises to civil action, and allowed SI to react against the preeminent neoliberal regime $[7,83]$ and the effects of the austerity context [76].

In addition, a participatory process launched in July 2012 by the Directorate of Culture to design the Strategic Cultural Plan of Madrid (PECAM) for 2012-2015 managed to assemble many cultural and social professionals and collectives in its working sessions. During a session in October, one of the working groups, with members from citizen initiatives, NUA professional collectives, researchers from the Spanish National Research Council (CSIC), and committed civil servants, decided to consolidate La Mesa Ciudadana (The Citizen Table) as an open and permanent research space. La Mesa Ciudadana and its spin-off working groups so became, for two years, a key experimentation space to share, map, and dissect urban experiences, collectively envision new spaces and tools for civil-public shared management, and experience the opportunities and contradictions of hybridizations of roles between civil, public, and private actors [11].

As time has shown, both the networking and experimentations developed by La Mesa Ciudadana and the innovation labs were fundamental to laying the basis for the new institutional arrangements and innovations implemented since 2015.

\subsubsection{Municipalism as a Binding Discourse}

Parallel to practical interventions and socio-spatial co-creations addressing direct consequences of the economic crisis, more radical actions and positions were held by those committed to the fight against evictions and foreclosures, mostly in low income 
neighborhoods. It is important to underline that the resources, tactics, and narratives of the different urban actors were not always coherent and aligned. For instance, NUAs tried to be more pragmatic, creative, and innovative than contentious or antagonist, however, there were spaces of encounter.

The philosophy of encounter and debate shared by $15 \mathrm{M}$ assemblies, NUAs, and other actors active in civil mobilizations including academics has facilitated gatherings among such actors to discuss their common concern about the democratic crisis and toward democratic innovation. Through a process of collective political debate and action-researchmostly around the Observatorio Metropolitano, a research-experimental collective linked to the book editorial Traficantes de Sueños-the principles of New Municipalism [12] emerged as a common discourse that could articulate the different concerns and demands that were being raised against neoliberal governments and deficient representative democracies [11]. Municipalism goes beyond the rejection of state institutions and aims at using and transforming them, starting with those closer to citizens at the local level, both to deal with the impact of globalization and to challenge the neoliberal political and economic order. It is also regarded as a particular answer to the democracy deficit [87], pursuing the democratization of local institutions and the distribution of power among citizens and urban actors (politics of proximity) [12]. As such, their claims for "radical democracy" relate both to principles from participatory and deliberative democracy.

From the participants of these debates, the core of a new civil platform, "Ganemos Madrid", took shape, which later joined other green and leftist political parties (Equo, Izquierda Unida, and later Podemos) constituting the independent political platform Ahora Madrid that was presented to the municipal elections in 2015 [79]. Ahora Madrid's program [88] was built through a participatory process and brought together by the interests of many civil organizations. Special stress was set on the enhancement of citizen participation, collaboration between administrations and civil movements, social and solidarity-based economies (SSE), and urban regeneration under the principles of urban justice and sustainable development, correlated to the agenda of progressive urban regimes.

\subsection{Democratic Innovation during the "Government of Change" (2015-2019) \\ 4.2.1. The "Government of Change" Led by Ahora Madrid}

In May 2015, against all odds and breaking more than 20 years of hegemony of the PP ruling the local administration, the pro-municipalism independent platform Ahora Madrid was able to govern the city backed by the socialists. The arrival of the new team opened previously inconceivable opportunities for institutional innovation included in their program [88] and re-located municipal efforts toward progressive agenda priorities that had been disregarded by previous governments. This rearrangement of priorities was evident in their Governing Plan [89] and was accompanied by a reorganization of the local administration and the integration of some NUAs and other activists and professionals that had been involved in the experimentations and networks described in the previous section, as part of the ruling team or as partners in the development of pilot projects and participatory programs, with the consequent transfer of experience and principles into the institutional framework. First, new specific areas in the local government were created (i.e., the new Directorate of Citizen participation, Transparency and Open Government led by Pablo Soto, activist from the $15 \mathrm{M}$ linked with the open culture movement, and the Directorate of Territorial Coordination and Civil-Public Cooperation, led by Nacho Murgui, former coordinator of the Regional Federation of Neighborhood Associations of Madrid (FRAVM)) [79]. Second, existing directorates were re-named, like the Directorate of Sustainable Urban Development, and commissioned to develop long-term strategic plans to address these issues as new urban priorities (ibid.).

Table 1 summarizes the main findings described in this section in relation to the categories of the analytical framework mobilized. 
Table 1. Main findings for the first section of the analytical framework: pre-conditions for innovative multi-actor collaboration (IMAC).

\begin{tabular}{|c|c|c|}
\hline Pre-Conditions & Sources/IMACs & Main Findings \\
\hline $\begin{array}{c}\text { Social and } \\
\text { political concerns }\end{array}$ & $\begin{array}{l}\text { Post-crisis austerity } \\
15 \mathrm{M} \text { Movement } \\
\text { Self-managed civil centers } \\
\text { Municipalism }\end{array}$ & $\begin{array}{l}15 \mathrm{M} \text { civil mobilization and experimentation in reaction to } \\
\text { neoliberal and austerity measures in post-crisis context. } \\
\text { Feeling of dissatisfaction with the Spanish representative } \\
\text { democratic system and calls towards "Real Democracy". } \\
\text { Critiques to restrictive existing Participatory Statute. } \\
\text { Emergence of Municipalism as binding discourse. }\end{array}$ \\
\hline $\begin{array}{l}\text { Power (im)balance } \\
\text { in governance }\end{array}$ & $\begin{array}{l}\text { State/Region vs. municipality } \\
\text { Traditional activists and private } \\
\text { partners } \\
15 \text { M claims } \\
\text { NUA \& SSE }\end{array}$ & $\begin{array}{l}\text { Lower competences and power of local level in post-crisis. } \\
\text { Developmental regime installed by the Partido Popular with } \\
\text { restrictive involvement of urban actors in governance. } \\
\text { FRAVM and traditional neighborhood associations as main (and } \\
\text { only) civil interlocutor with administration. } \\
\text { New Urban Activists and SSE new political and economic actors } \\
\text { with greater technical and network capacities. }\end{array}$ \\
\hline $\begin{array}{c}\text { Cracks in } \\
\text { institutional setting }\end{array}$ & $\begin{array}{l}\text { Department of Culture } \\
\text { PECAM Plan } \\
\text { Innovation labs }\end{array}$ & $\begin{array}{l}\text { Hybridization of roles of urban actors and emergence of } \\
\text { individual and collective champions in the administration. } \\
\text { Specific policy areas and topics foster and fund NUA. }\end{array}$ \\
\hline $\begin{array}{l}\text { Previous relations and } \\
\text { collaboration experi- } \\
\text { ence }\end{array}$ & $\begin{array}{l}15 \mathrm{M} \text { Assemblies } \\
\text { Self-managed civil centers }\end{array}$ & $\begin{array}{l}\text { NUA and civil networks created and/or reactivated. } \\
\text { Local administration champions (individuals, agencies and } \\
\text { directorates) involved in experimental collaborations. } \\
\text { PECAM Plan and La Mesa Ciudadana build a network of actors } \\
\text { and projects concerned about MAC and CPC. } \\
\text { Collaborative evolution of Ahora Madrid and its program. }\end{array}$ \\
\hline $\begin{array}{l}\text { Previous governance } \\
\text { experimentation }\end{array}$ & $\begin{array}{l}\text { Networks of citizen initiatives } \\
\text { Urban (cultural) experiments } \\
\text { PECAM Plan } \\
\text { Neighborhood Programs } \\
\text { Mesa Ciudadana } \\
\text { Observatorio Metropolitano } \\
\text { Ahora Madrid program }\end{array}$ & $\begin{array}{l}\text { NUAs mobilize bottom-up co-productions in vacant spaces and } \\
\text { vulnerable areas and experiments on collaborative and network } \\
\text { governance, collective intelligence \& open culture. } \\
\text { Civil-public interactions around demands in certain areas: } \\
\text { co-management of public spaces, neighborhood plans. } \\
\text { Networking and collaboration in the participatory process to } \\
\text { design the PECAM Plan and subsequent co-research. } \\
\text { MAC debate and evolving coalitions building around the birth of } \\
\text { Ahora Madrid and its participatory program. }\end{array}$ \\
\hline
\end{tabular}

We identified three subsequent strategies followed during the government of Ahora Madrid related to institutional innovation that fostered IMAC and led to urban regime change. First, the existing institutional framework was "hacked" to enable incipient experimentation with alternative ways of integrating the emergent urban actors and networks explained in the previous section in policy making. Second, new governance and institutional mechanisms were developed in parallel with the two newly created directorates just introduced to enhance direct democracy and collaborative/deliberative democracy, respectively. The work from these directorates continued the trajectory of experimentation with the principles of open culture and radical participatory democracy on one hand, and collaborative and deliberative democracy on the other, which had driven civil mobilization in the previous period. These efforts were combined with those toward the decentralization of power from City Hall to the District Boards and to decentralize and re-balance power and resource allocation within the administration and among territories and actors in the city $[11,85]$. Third, such mechanisms were mobilized from different directorates and policy fields to develop long-term strategies and pilot projects around the renewed agenda priorities by means of activating IMACs able to integrate resources and expertise from different urban actors, especially from civil society and SSE, that had been left aside in previous times. Figure 2 gives an overview of the main mechanisms and policies developed regarding direct democracy and collaborative governance and the subsequent plans 
and co-creations in which they were applied from other policy fields, which are further analyzed in the following sections.

\subsubsection{Institutional Innovations Implemented by Ahora Madrid between 2015-2019}

The first attempts to integrate new voices and perspectives in policy making consisted of revising and "hacking" the existing institutional framework, specifically, the participatory mechanisms contemplated in the Participatory Statute of Madrid [90]. For instance, the Public Audience, already included in such a document as a tool to summon citizens to discuss a specific issue and establish direct dialogue between civil society and the administration, was revived. Under this formula, Mesas Ciudadanas ("Citizen Tables") were organized in which citizens, experts, civil, and private organizations were invited to evaluate on-going large scale urban plans like Operación Calderón and Distrito Castellana Norte [91] and to co-design contra-proposals in line with the principles embraced by the new governing team. Further on, in March 2018, the statute was updated to integrate some of the new procedures described in this section. Additionally, the "cracks" and incipient CPC identified in the previous period kept being used, and the innovation labs remained key spaces for collective discussions and to foster MAC and SI.

The Directorate of Citizen participation, Transparency and Open Government and the Directorate of Territorial Coordination and Civil-Public Cooperation work in parallel in the development of new governance mechanisms to foster direct democracy and participatory governance and collaborative and network governance, respectively. In this regard, the theoretical discussions between the proponents of direct or deliberative democracy discussed in Section 2 are also evident in the differing and sometimes conflicting mechanisms and strategies pursued by the two teams, sometimes developed "in parallel" instead of through collaboration between directorates. For instance, direct democracy tools and voting sessions can foster an "individualistic" participatory approach, although, in many cases, their implementation is complemented with "didactical and deliberative" events and governance mechanisms. However, it should be noted that "Municipalism" as an umbrella ideology is not enough to settle conflicts arising from different perspectives regarding democratic innovation and the role of the local administration in urban governance, discussions on the urban model to be pursued, and differing ideas on how to address urban development, which provoked an internal "schism" within the coalition of Ahora Madrid by the end of the legislature [91]. 


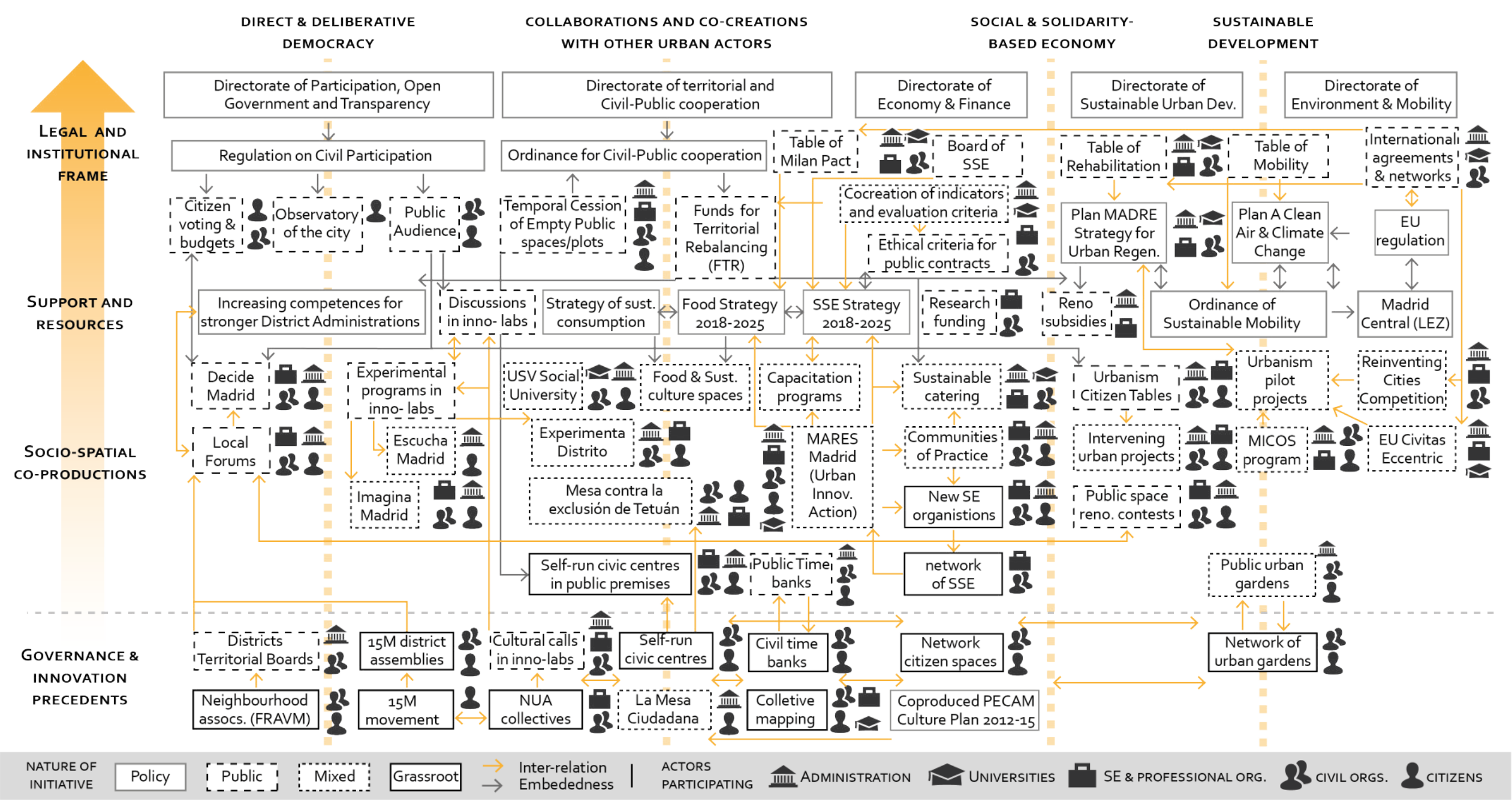

Figure 2. Main findings for the second section of the analytical framework: socially innovative multi-actor collaborations (IMACs) and enabling policies, plans, and tools implemented during the period of democratic innovation in relation to the precedent experimentations explained in Section 4.1. 
The first and main tool implemented to foster direct democracy and participatory governance was the online platform Decide Madrid [92], a digital translation of the Public Audience. The platform ran with Consul, an open software developed by City Hall itself, and was launched in September 2015 as a virtual public space that allowed residents to join debates and voting sessions, raise and support proposals, and contribute to specific policy-reviewing debates proposed by the administration. On February 2017, the first voting session of citizen proposals took place, combining digital voting with traditional envelopes sent to all homes and information and voting stands in the streets to increase the diffusion of proposals and participation. A similar procedure was later used to obtain citizen feedback in different stages of design competitions for square renovations between 2016 and 2017 and, since 2017, for collecting and selecting proposals in the Participatory Budgets. These participatory processes that rely on individual proposals and voting can be criticized for their risk in growing individualistic behaviors and their tendency to avoid conflict and generate post-political consensus [93]. However, Gibson-Graham and Roelvink [94] also emphasized how, apart from giving voice to the local population in relevant decision-making and increasing political awareness, they could contribute to increasing community awareness and interdependence acknowledgment, prompting participants to articulate their individual needs in relation to community needs. Along this line, a stage to gather popular support was included before listing the shortlisted proposals in the Participatory Budgets in 2018 and 2019, and street-voting and information stands accompanied the online voting procedure [95].

Furthermore, aligned with pro-commons and open culture movements, the ConsulCON convention was organized yearly to help improve and spread the Consul software for new uses and users around the world. In its last edition, the Observatorio de la Ciudad (Observatory of the city) was presented, a new mechanism aiming at both direct and deliberative democracy. Inheriting the name of a pre-existing consulting board, it was first conceived in the Democratic Collective Intelligence 2017 workshop organized in Medialab Prado and learnt from other randomly selected citizen assemblies established worldwide to revive deliberative and representative democracy [96,97]. Constituted in March 2019, it integrated 49 citizens chosen by lot for two years that would meet eight times a year to evaluate and audit proposals from Decide Madrid and the performance of the City Council and the other political parties.

In parallel, the first efforts to advance in the integration of organized civil movements in policy and city making aimed at supporting and strengthening civil organizations and increasing their influence by facilitating their access to public resources and public bids and programs. Soon, the Guidelines for Cession of Public Spaces to Citizen Entities were approved in February 2016 [79] with the aim to institutionalize what had been "anecdotic and discretional" "free leasing" agreements in the previous years and to introduce transparency and clear criteria to the process. It also meant an attempt toward the CPC legalizing the "out of the law" activity of squatter movements and self-managed civic centers. Finally, after years of collaborative design with civil organizations, an Ordinance for Public-Social cooperation [98] was approved on 19 April, 2018, as a counter-part for the well-established regulations for private-public partnerships (PPP). Its objectives were to regulate the engagement of active citizens in policy-making, fighting poverty, and exclusion, promote the emergence of new spaces for development of the commons, take advantage of shared knowledge, and promote social innovation and cohesion [99]. It included, among other issues, guidelines for the co-management of public premises, mechanisms for different types and degrees of collaboration and sharing of resources between civil and public actors and criteria to allocate the Funds for Territorial Rebalancing (FTR) among non-profit organizations, which we will explain later.

In addition, procedures of public procurement were revisited, partly within the development of the strategy to promote SSE, by adding social and ethical criteria to the technical and economic aspects already regarded as well as dividing big contracts into smaller lots. The philosophy behind this strategy was to increase the amount of money made available 
to support initiatives and actors aligned with the priorities and philosophy of the new governing team by opening the door to smaller companies and those within the SSE that did not manage to meet the criteria for public allocation under the previous regulation. For instance, the application of ethical and sustainable criteria in the allocation of the contract for energy provision in municipal premises in 2018 left out of the competition the big national energy companies that had monopolized this budget in the past. Despite the lawsuits filed by such companies against the local government for not abiding by the principles of free and fair competition, the Madrilian court finally backed the actions of the municipality.

Complementary practices, born as organizational mechanisms in the civil movements, have been institutionalized as tools for participatory governance applicable to all residents, the most important one being the Foros Locales (Local Forums) [100], which institutionalized the "neighborhood assemblies" that had spread after the $15 \mathrm{M}$. These new "shared spaces" were established in the 21 districts in February 2016, substituting the previous Consejos Territoriales (Territorial Boards) [79] as a place for discussion among volunteer citizens, non-profit organizations, and district administrations with the power to raise proposals to the District Board and audit their activities. Each forum, and their thematic working tables, were allowed to meet in public premises, provided with a "dynamizer" or facilitator, and allocated a budget to self-organize workshops, events, and activities for the district. These forums and their thematic working tables were regarded by the different directorates as legitimate representatives of organized civil society to be addressed and incorporated in different projects and policy-making processes. For instance, urbanism tables were involved in the development of the design criteria of the square renovation competitions. In addition, the Network of Local Forums was created in May 2017 for inter-district collaborations, while specific training sessions were also run to increase the deliberative skills of participants. To a certain extent, the Local Forums acted as the collective counterpart of the individualistic use of Decide Madrid, namely, by articulating collective proposals for the participatory budgets and performing collective audits of proposals and sharing such evaluations before the voting stages. However, the necessary degree of institutionalization and procedural formalization required to legitimate these forums [79] and the conflict between them and traditional civil organizations, in terms of collective representation, sometimes limited the degree of participation and appropriation of these spaces by civil actors.

The aforementioned innovations were accompanied by a restructuration of local governance at the institutional level. Not only were District Boards reassigned competences that had been progressively centralized, like the management of some cultural, leisure, and gardening facilities and bureaucratic responsibilities, but new mechanisms were set to provide districts with more resources and decision power [85]. The Local Forums and district-specific participatory budgeting already played a key role in providing social movements and citizens with resources to affect politics at the neighborhood level, however, the FRT [101,102] was the main innovation created to provide district boards with extra funding to tackle social and urban deficiencies and vulnerabilities. In cooperation with Carlos III University, socio-economic criteria were devised based on empirical indicators from different institutions to ensure that such funds were distributed among the most vulnerable areas. The combination of the FRT and collective proposals in the participatory budgets allowed for the development of projects that would have found it difficult via public financing in previous times [103].

\subsubsection{Resulting IMACs and Outcomes}

All the aforementioned governance and institutional innovations set the basis for the further emergence of more or less formalized IMACs to advance in the development of urban experimentations and specific projects, plans, strategies, and policies from different policy areas. The combination of the new mechanisms with already established ways of networking and partnering managed to attract and include key stakeholders, experts, 
professionals, and institutions related to the new agenda targets, most of which had not managed to influence policy-making in the past. The aim was to develop transsectoral long-term strategic plans and visions with broad participation and consensus among different urban actors to transform the way local politics was performed in the city toward deliberative democracy. Additionally, transversal and inter-departmental coherence was sought, which resulted in integrating plans and strategies from one policy area in those developed from other areas, thus building a strong and coherent local strategy. As we explain in the following lines, at least four types of IMACs contributed to achieve these objectives.

One first kind of IMAC was developed within deliberative and co-creation processes and were institutionalized through the consolidation of sectorial advisory boards. These included representatives from different levels and areas of public institutions, companies, research centers, and civil and professional associations. While numerous Consejos Sectoriales (thematic advisory boards) already existed as consultative boards, during this period, new boards were established, most of which were Mesas (Tables), conceived as spaces for collective deliberation, diagnosis of state of affairs, and the development of proposals. These thematic tables continued to be applications of the Public Audience explained in the previous section and reminders of the La Mesa Ciudadana that had been gathering before 2015 in Medialab, hinting toward new relationships within and with these bodies. The new boards, like the Table of Rehabilitation and Urban Regeneration [104] and the Table for the supervision of the Milan Pact [105], together with the already existing Table of Mobility, were regularly summoned to inform and track the processes of the research, design, and implementation of plans and strategies, namely the Plan MAD-RE for sustainable urban regeneration [106], the Strategy for Sustainable and Healthy Food [107], and the renewed Ordinance of Sustainable Mobility [108], respectively.

A second, yet related type of IMAC emerged from a "hack" of traditional outsourcing practices by which organizations from civil society, SSE, or knowledge institutions were commissioned to develop preliminary diagnosis reports, facilitate participatory processes, and draft intermediate and final documents of these strategies in order to complement the resources of the public administration with the skills, expertise, and prior experience of these organizations in each of their specific fields of practice [109]. For instance, Surcos urbanos, a team combining activists and actors from academia and the social economy, developed the Strategy for Sustainable and Healthy Food, and a partnership between the cooperatives Aquo, Dinamia, and Tangente led the Strategy to promote SSE.

A third less formalized type of IMAC occurred during open information and deliberation sessions organized by the City Hall as intermediate steps in the participatory development of these plans, to which individual citizens and key stakeholders were invited. For instance, apart from the already explained ConsulCON and other "citizen labs" held in Medialab to explore the possibilities to increase democratic innovation, several workshops and online and offline brainstorming sessions were organized during the development of the Strategy for Sustainable and Healthy Food [107] (p. 60). The Directorate of Economy also organized the Municipal Forum of the SSE and a 2-day event to present and discuss the SSE diagnosis and the final document of the Strategy for SSE, respectively [110] (p. 15). Meanwhile, the Plan MAD-RE relied on the input from debates with academics, experts, and citizens and workshops with the urbanism tables from the Local Forums [106] (pp. 14-18, 132-133). All of these events also served as educational and networking spaces that contributed to strengthening the network of actors around each topic and kept alive the broader debates regarding municipalist principles and the urban model to be pursued in the city that had started in previous years.

In parallel to the development of the strategic plans, different "formulas" were explored to institutionalize more practical IMACs aimed at developing pilot projects to test and advance the design and implementation of policies, strategies, and plans. On the one hand, Intermediae and Medialab Prado continued to host and fund initiatives like Imagina Madrid and Experimenta Distrito, which explored new possibilities for engaging 
citizens and civil organizations in artistic and/or urban space collective productions [86]. Furthermore, pilot urban experiments that blended research and experimental action were outsourced or approved and funded through the participatory budgets, like the Micos project [111] led by Pez Arquitectos, or the Itinerarios Habitables pilot projects [112] led by the inter-disciplinary team Improvistos, both under the umbrella of the Plan MAD-RE. On the other hand, IMACs were created to take advantage of the opportunities offered by international institutions and programs. For instance, City Hall partnered with universities and companies to participate in European programs like Civitas Eccentric to co-design and implement bike-lane pilot projects, thus expanding the notion of the neoliberal PPP. The same principle inspired the project MARES Madrid, a rare socio-spatial and economic experiment in which neither City Hall or a private or social entity held exclusive ownership or leadership. Instead, it was jointly designed and run by a consortium of seven NGOs and organizations from the SSE (TxP, VIC, SIC, Tangente, Ecooo, Dinamia, and Acción contra el Hambre) together with different agencies from local government, co-financed for four years by the European Union as an Urban Innovative Action. The name of the project, designed to activate urban transformation though social economy, responded to five key economic fields targeted: Movilidad (mobility), Alimentación (food), Reciclaje (recycling), Energía (energy), and cuidadoS (care). Four Mares (seas) were settled in underused public buildings or plots in different vulnerable neighborhoods, each one dedicated to the research and implementation of alternative productive and economic models within SSE in one of the aforementioned fields, care being transversal in all of them. The "seas" coordinated sectorial and territorial diagnosis, fostered, and guided emerging businesses through the SEE economic models and processes, run pilot experiences that supported the development of the strategies already explained and enhanced networking and exploration of alternative futures and opportunities in each of the fields with learning communities that involved all kinds of individual and collective stakeholders.

Finally, it should also be stressed how the IMACs that were developing these pilots and strategies replicated strategies already practiced by civil organizations prior to 2015, seeking international partnerships and agreements to strengthen and legitimize the common agenda. This was the case with the adherence to the Milan Urban Food Policy Pact and the organization of working sessions on sustainable urban regeneration with UN Habitat. Additionally, the internationalization of the city changed the priorities of the municipality, reinforcing commitments with Latin American cities through the existing Iberoamerican Capital Cities Union (UCCI), supporting new political city networks with progressive cities and progressive agendas and Agreements (C40, Habitat III, Fearless Cities ... ), and organizing gathering events like Cities for Peace in Madrid.

Most of the policy outcomes of this work came out almost at the end of the legislature term as a result of the long deliberative and experimental process behind each of them. Although each plan was developed for a specific purpose and coordinated from a specific administrative area, a special effort was made to enhance inter-disciplinary and inter-departmental collaboration and coherence involving all the affected administrative areas and stakeholders in the deliberative process of policy co-creation, which resulted in numerous interconnections among plans. For example, the "low emission zone" Madrid Central was included and supported simultaneously by the Plan A for air quality approved in September 2017 [113], the renewed Ordinance of Sustainable Mobility was passed in October 2018 [108], and the Plan MAD-RE was also approved in 2018 [106]. Many interconnections were also established among them the Plan to promote sustainable consumption, which was approved in 2017 [114], the Strategy of SSE, which was approved in 2018 [110], and the Strategy for Sustainable and Healthy Food was approved in 2019 [107].

\subsection{Post-2019 Conditions: Assessment of Urban Regime Change}

In May 2019, the conservative PP managed to regain the local government, backed by the liberal and far right parties. Despite the short period of analysis remaining and the special socio-political circumstances derived by the COVID-19 crisis, in this section, we tried to assess 
the stability of the institutional and strategic innovations implemented during the ruling period of Ahora Madrid and their consequences in changing the political culture of the city. In the Government Plan of the new team for 2020 [115], a strategy of contestation and abolition of all advancements and plans achieved by Ahora Madrid was evident, regarding both democratic innovation and specific sectorial strategies and plans. However, the PP-led government did not manage to abolish all the plans aimed, at least as fast as they had expected, while some of their new proposals showed an underlying influence of the advancements of the previous legislature.

In terms of participatory and deliberative mechanisms, one of the main objectives of the new government was to "revise" them with the aim to elaborate a new participation model, situating Information and Communications Technology (ICT) as a main tool for participation" [116] (p. 3). In this process, the platform Decide Madrid was consolidated as the means of communication between the administration and citizens to meet the legal requirements for the compulsory "information stage" preceding the development of any new policy. However, all other deliberative and participatory utilities were stopped, which included the participatory budgets, which were not organized in 2020, while the implementation of 237 previously approved proposals was cancelled, alleging unfeasibility after a process of internal audit [117]. Offline information and deliberative events were also no longer organized, while the rare processes of collective ideation, for instance, ideas for some of the initiatives for urban regeneration, aimed at collecting individual design proposals, thus enhancing the individualistic character of these tools without a collective counterpart. Along the same line, the Observatory of the City was soon abolished and the Local Forums, which were forced to cease their activity during the COVID lockdown, were transformed into "Proximity Councils", eliminating their facilitation role and restricting the number of participants and their competences, especially in terms of auditing municipal performance [118]. However, the institutionalization of some IMACs as "Tables" working on new policy niches and their relation to supra-local networks and agenda priorities has given them legitimacy to continue with their work, as was the case with the Table for the supervision of the Milan Pact. After a year of demands from the organizations involved [119], meetings resumed [120], which gave such organizations the momentum to continue with parallel collaborations and actions as well as opportunities to continue collaborating with the local administration despite the "official" change in priorities [121].

In relation to the wider strengthening and support of organizations from civil society and SSE, the first line of action from the new government team was to abolish some of the ongoing leasing agreements with civic centers and collectively managed public spaces and premises and to audit, and even cancel, some of the pending payments to organizations from the SSE. Additionally, the process to derogate the ordinance of civil-public collaboration started in early 2020 [122]. These and other actions triggered suspicion toward the new ruling team among civil and economic organizations that had been involved in policy and citymaking projects in the previous period. This pushed civil mobilization and collective action back to alternative networks to those enabled by the institutional framework and triggered a strategy of protest and contingency against every new plan announced. This was especially evident during the consolidation of citizen solidarity and collective support for initiatives mobilized during the COVID crisis. These rejected being coordinated by public institutions or incorporated in municipal websites or plans [123], and rather created alternative networks that criticized the public management of the crisis and requested public resources to continue their activities [124,125]. The mapping exercise of such solidarity initiatives emerging in the COVID crisis [126] has already shown how networks and relations among actors have continued to re-articulate and collaborate in innovative ways. Even some IMACs involving the local administration have emerged in this context, like the solidary urban gardens program [127].

Members that had been part of the Ahora Madrid government reflected on the fact that the processes of collective experimentation with CPC had forced readjustments both in civil organizations and in public administrations. For instance, civil "collectives" had to adapt their legal organizational requirements and structures, even if it was only "on paper" to abide to the administrative processes of collaboration with the administration [2]. They also acknowledged 
their previous ignorance about the working mechanisms of public administration, which impeded them in advancing at the speed that they expected as well as the weight of the agreements and policies already subscribed by previous teams and the initial suspicions raised by their arrival as civil servants. Retrospectively, they celebrated the internal knowledge gained during the ruling period that could now be transferred to continue contingency actions back from civil movements or from the opposition.

They also stressed the strong effort made to remodel procedures and skills within the public administration and the importance of trying to "do things right" when integrating all new agreements, strategies, and governance mechanisms in policies and public plans, which made them more difficult to abolish, and therefore affected future politics. Additionally, the fact that actions and projects were embedded in multiple documents was key as well as the broad consensus built around such documents during participatory processes, as evidenced in the unsuccessful attempt to abolish "Madrid Central" in the first months of the legislature. Along this vein, it is interesting to notice the rebranding strategy followed by the new team in relation to the strategy for urban regeneration. Instead of forgetting or abolishing the MAD-RE Plan, it was "translated" into an unlabeled "urban strategy" [128]. Furthermore, most of the strategies and projects foreseen for the time-frame of the new legislature such as the Metropolitan Forest and the Inclusive Itineraries, kept being developed, although advertised under the umbrella of a supposed new "clean air strategy", the 360 Strategy [129], while allusions to the MAD-RE Plan were restricted to the calls for subsidies for real estate renovations.

Table 2 summarizes the main findings described in this section assessing how IMACs contributed to urban regime change in relation to the categories of our analytical framework.

Table 2. Main findings for the third section of the analytical framework: post-conditions.

\begin{tabular}{|c|c|c|}
\hline Post-Con & Sources/IMACs & Assessment of Urban Regime Change \\
\hline Political Agenda & $\begin{array}{l}\text { Ahora Madrid } \\
\text { New priorities \& new } \\
\text { directorates }\end{array}$ & $\begin{array}{l}\text { Government agenda as per collaborative political program. } \\
\text { Work advanced from "progressive" political fields, especially those not } \\
\text { previously developed from neoliberal logics. }\end{array}$ \\
\hline $\begin{array}{l}\text { Actors in } \\
\text { governance networks }\end{array}$ & $\begin{array}{l}\text { Decide Madrid } \\
\text { Local Forums } \\
\text { Citizen tables } \\
\text { Bid allocations } \\
\text { Cross-sectoral collaboration }\end{array}$ & $\begin{array}{l}\text { Involvement of civil society in its diversity, including NUA, SSE } \\
\text { organizations and individual citizens in policy and city-making. } \\
\text { Hybridization of roles. Cross-relations among actors in different networks } \\
\text { with different roles: advisors, contractors, citizens ... } \\
\text { Integration of the local administration in international networks } \\
\text { multi-level governance for broader legitimacy and resources. } \\
\text { Hacking of existing tools finding new ways of using them. }\end{array}$ \\
\hline Institutional setting & $\begin{array}{l}\text { Learn-by-doing } \\
\text { Legal binding } \\
\text { Participatory mechanisms } \\
\text { Transversality }\end{array}$ & $\begin{array}{l}\text { Update of Ordinance of Public Participation and bidding criteria. } \\
\text { New policies reframing MAC from } 2 \text { "ad hoc" directorates applied in } \\
\text { policy-making and projects from other policy fields. } \\
\text { Co-development and management of plans and projects. } \\
\text { Transversal, long-term and cross-embedded planning. }\end{array}$ \\
\hline $\begin{array}{l}\text { Sharing of resources } \\
\text { and empowerment } \\
\text { of actors }\end{array}$ & $\begin{array}{l}\text { Decentralization } \\
\text { FRT Fonds } \\
\text { Local Forums } \\
\text { CPC \& SSE rules } \\
\text { Ethical public procurement }\end{array}$ & $\begin{array}{l}\text { District Boards with new competences and bigger resources. } \\
\text { Extra budget allocated as per vulnerability and sustainable criteria. } \\
\text { Institutionalization of "shared spaces" with specific resources. } \\
\text { Sharing public resources and biddings with civil and SSE actors. } \\
\text { Projects/policies developed around common wicked concerns, mobilizing } \\
\text { wider and more specific range of actors and resources. }\end{array}$ \\
\hline $\begin{array}{l}\text { (In)stability of } \\
\text { networks } \\
\text { and outcomes }\end{array}$ & $\begin{array}{l}\text { Long-term strategies } \\
\text { Legally binding } \\
\text { MAC legitimacy } \\
\text { CPC regulation } \\
\text { Strengthening of civil actors } \\
\text { \& administration } \\
\text { Solidarity networks }\end{array}$ & $\begin{array}{l}\text { Approval of inter-related long-term strategies and policies co-developed } \\
\text { through IMACs for broader legitimacy and survival. } \\
\text { Conflicts within Ahora Madrid coalition brought to "schism". } \\
\text { Lack of support and continuity from new government team (PP). } \\
\text { Still, many instruments remain or are being adapted by PP, therefore some } \\
\text { change has been consolidated. } \\
\text { Network of actors keeps evolving. Government of change period } \\
\text { strengthened civil actors and IMAC networks and updated inner } \\
\text { administration so that they keep re-articulating and collaborating even } \\
\text { when some plans were stopped and the COVID crisis arose. }\end{array}$ \\
\hline
\end{tabular}




\section{Discussion and Conclusions}

We started this paper by conceptualizing innovative multi-actor collaborations (IMACs) as a multi-actor governance arrangement that could be socially innovative and contribute to democratic innovation. We developed a three-fold analytical framework for this study by combining perspectives from SI, public governance, and urban regime change theories. We applied this framework to the case study of Madrid during the "government change" of 2015-2019 to further analyze why and how these IMACs emerge, the institutional mechanisms and governance innovations that support their emergence, and to what extent and how IMACs contribute to governance innovation and urban regime change.

In relation to the conditions of possibility for the emergence of IMACs, one important pre-requisite we identified was the pre-existence of networks of actors around progressive issues and sedimentation of social experimentation within the cracks of the previous neoliberal developmental urban regime. However, these only achieved real potential to gain power to act, affect politics, and change the urban regime when civil and political interests aligned in a "conflict moment", namely the entry of the municipalist coalition Ahora Madrid in the local government. From this position, Ahora Madrid managed to include progressive issues that had not been addressed as priorities from a neoliberal perspective in the urban agenda, i.e., democratic innovation, sustainable urban regeneration, and spread of SSE. They also managed to implement governance innovations that institutionalized some of the multi-actor experimental collaborations in which civil and professional actors and champion civil servants, public agencies, and administrative areas from specific directorates had been involved in previous years. Not only did previous collective learnings inform the new model of urban governance, but people who had also been involved in previous experimentations and debates were assigned to lead the evolution and translation of the civil experimentation into the institutional level from new directorates. Political will was thus also revealed to be essential to empower actors that had been losing their political capacity of influence in the production of the city and to involve them in new IMACs to advance a progressive agenda, especially civil, SSE, NUAs, professional organizations, and individual citizens. Along the process, municipalism was key as a common discourse that managed to mobilize and connect a wide variety of actors around the same agenda priorities and general lines of action. However, discrepancies in the translation of its broader principles into specific actions in local policies resulted in sometimes contradicting mechanisms and strategies in urban politics, and, eventually, to an internal split within the governing coalition.

The institutional innovations implemented by the local government led by Ahora Madrid that enhanced the possibilities for IMAC started by "hacking" the existing policy framework and copying strategies already used outside public policy processes in previous years. Meanwhile, new mechanisms were designed and implemented, fostering participatory and deliberative democracy, CPC, re-balanced access to power and public resources, and co-management among the urban actors. The combination of old and new mechanisms from different policy areas allowed the articulation of a wide variety of more or less formal IMACs and fast experimentation with pilot projects to advance addressing the new progressive agenda issues. This heterogenous mix of MACs complemented the widespread (neoliberal) public-private partnerships (PPP) based on public bids and subcontracting service provision from the public administration to private for-profit actors. Instead, IMACs have explored newer ways of co-design and co-implementation, acknowledging and deliberatively integrating a wider diversity of actors and values that have a stake in urban governance, other than the economic priorities normally identified by "private" actors. Such an approach could help advance the definition and implementation of transversal and long-term policies and strategies in different policy fields. Along this process, institutional innovation learnt and evolved from both previous social mobilization and CPC, and from the new "situated experiences" and pilot projects that were conducted with the new governance mechanisms. These are the requirements already pointed out by Healey for a "people-centered polity to emerge" [48] (p. 34). 
IMACs are also relevant to renew the public administration machinery. First, strong efforts have been made to establish and coordinate trans-sectoral collaborations between people and agencies from different administrative areas. Second, IMACs have been used to review and complement skills and resources previously lacking in certain areas of the administration, especially those related to new progressive issues introduced in the urban agenda (e.g., social economy) through collaboration with non-public actors such as NUAs and SSE organizations. They have also tested and institutionalized new formulas for consortiums of citizens, civil movements, private organizations, and multi-level and transdisciplinary administrations, and shared knowledge and resources. Furthermore, the reconfiguration of urban actors involved in local governance has effectively limited the power of certain actors including richer and more advanced neighborhoods, market lobbies, or the FRAVM, previously almost the only interlocutor between civil society and the administration. The integration of agents from the SSE in policy and city-making was also ensured thanks to the development of a specific strategy for SSE and the definition of dedicated shares in public procurement, while guaranteeing fairer competition in the allocation of public contracts by establishing smaller allocation lots and including social and environmental criteria.

After reviewing the process and results of the democratic governance innovations and the IMACs, we can revisit our assumption that they contribute to a transition process toward a progressive urban regime. However, such a process cannot be labelled as bottom-up nor top-down. Pre-established relationships, experimental networks, and democratic and social innovations, conducted mostly from the social sphere, laid the foundation for changing the urban regime and governance mechanisms when Ahora Madrid gained power. In the landscape of IMACs, "agency is constituted by social connections that activate assets already present in the community in ways previously unrecognized, underutilized, or simply not accessible in a manner relevant to the community's needs and aspirations" [130].

The results bring about two additional learnings regarding the actors involved in urban regime change. First, local administrations were multi-layered entities, in which some individual civil servants and/or public agencies acted as champions in incipient experimentations that paved the way toward further collaborations, or managed to continue with the IMAC even in an adverse post-2019 context. This also exposes itself in terms of multi-level governance. Complex relationships are evidenced between the local government and administration as well as (1) district boards and politics and (2) supra-local administrations and agencies. Second, the ongoing process of the hybridization of roles in local governance was also evident and enriching. This process manifested itself in dynamic cross-relations between networks and MACs, and differing roles and positions taken by individual and collective actors in different moments and projects (i.e., acting as citizens, experts, activists, civil servants, advisors, contractors, partners, and auditors).

Regarding the extent to which IMACs gained power to act and the stability in time of their processes and outcomes, certain strategies related to multi-level and meta and hybrid governance theories [55] need to be highlighted. First, legitimacy and possibilities for endurance over time were increased and secured in some cases. This was due to the combined strategies of seeking and receiving ratification and resources from supranational institutions and building broad consensus around policies and plans by means of involving a wide variety of stakeholders (and their interests, logic, and resources) through IMACs and participatory processes. In addition, inter-disciplinary and transversal work among policy areas resulted in difficulties in abolishing policies and projects embedded simultaneously in several sectoral policies and plans. Furthermore, innovation labs that had managed to "host" counter-current voices and innovative initiatives in previous legislatures remained as key intermediate actors and spaces during the ruling period of Ahora Madrid. They trepresented both powerful spaces for further inspiration and IMAC experimentation, and tools for "voicing" municipal efforts and strategies toward alternative democratic and socio-economic models. Moreover, they recovered their nature as "safe spaces" for actors, 
networks, and MACs to rearticulate and continue with collective experimentation and action once the PP re-entered the local government in 2019. Even then, many instruments have remained and/or were adapted by the new government, which shows how some change in the political and democratic culture of the city has been consolidated.

All along, IMACs have served to strengthen and empower the many individual and collective urban actors involved and the networks in which they participated through the exchange of experiences, skills, and resources and the establishment of new connections with other actors. This aspect of IMAC increases the resilience of actors and networks, which are in continuous evolution. It also allows them to re-articulate and extend the networks through which they connect and collaborate in times of adversity, or when some institutional mechanisms or strategies are cancelled (e.g., during the new legislature led by the conservative party and the COVID crisis).

In light of the aforementioned results, the three-fold analytical framework allowed us to study IMACs from complementing perspectives. The case of Madrid proved revealing in terms of reaching a richer understanding of the contribution of IMAC in the development of new progressive urban regimes. We argue that this framework and the results will be useful for further research and practice related to IMACs from different disciplines. Specifically, in relation to debates on SI, the framework can complement the perspective from civil society with the understanding of the role of local administrations and institutional frameworks in the emergence and success of SI. Regarding debates from public governance and urban regime change, it can help situate governance innovations in their socio-spatial and temporal framework and gain a richer understanding of the actors, roles, and institutions that contribute to democratic innovation.

To conclude, we refer to a few avenues to deepen the understanding of IMACs. The application of the framework to other contexts and cases would be the first way to enrich such conceptualization, acknowledging the limitations of our research based on a single case study. Further research could also expand the analysis to the specific application of the different governance mechanisms implemented. Such deepening would shed light on how IMACs have emerged in specific policy fields and geometries of the city, and how different governance levels and urban actors were coordinated in the process. Complementary, it would be interesting to deepen the understanding of the SI and hybrid governance process(es) that occur during IMAC and the specific contribution of public administration and other actors involved in them, which would move us beyond the dichotomy between civil-public collaboration and public-private partnerships.

Author Contributions: Conceptualization and methodology, C.M.-G., R.d.l.F., and P.V.d.B.; Formal analysis, C.M.-G. and R.d.1.F.; Investigation, C.M.-G. and R.d.1.F.; Writing-original draft preparation, C.M.-G.; Writing-review and editing, C.M.-G., R.d.1.F., and P.V.d.B.; Visualization, C.M.-G. All authors have read and agreed to the published version of the manuscript.

Funding: This research and the APC were funded by Fonds Wetenschappelijk Onderzoek-Vlaanderen (FWO) SB PhD Fellowship number $1 \mathrm{~S} 46920 \mathrm{~N}$, and this work has been supported in part by the Ministerio de Economía, Innovación y Competitividad (Spain) through grant 'CITiTALENT', CSO201674888-C4-4-R (AEI/FEDER, UE).

Institutional Review Board Statement: The study was conducted according to the ethical guidelines of the UCM and KU Leuven universities following The European Code of Conduct for Research Integrity by ALLEA All European Academies (https:/ / www.allea.org/wp-content/uploads/2018/01/ SP_ALLEA_Codigo_Europeo_de_Conducta_para_la_Integridad_en_la_Investigacion.pdf). Analysis and data interpretation were part of a research project approved by the Sociaal-Maatschappelijke Ethische Commissie (SMEC) from KU Leuven, n. G 2019121891.

Informed Consent Statement: Not applicable.

Data Availability Statement: The data presented in this study are available on request from the corresponding author.

Acknowledgments: The authors would like to thank the colleagues that enriched this research with their comments during the GSSI International Seminar SI in Southern European Cities (Italy, June 2019) and the 4th International Conference on Public Policy (ICPP4) (Montreal, July 2019) in which 
the intermediate advancements of this investigation were presented. Our gratitude also extends to the members of Ahora Madrid and other participants from MACs for sharing their time and experiences with the researchers over the years. Finally, we also wish to thank the reviewers who helped improve this manuscript with their valuable comments.

Conflicts of Interest: The authors declare no conflict of interest. The funders had no role in the design of the study; in the collection, analyses, or interpretation of data; in the writing of the manuscript, or in the decision to publish the results.

\section{References}

1. Belda-Miquel, S.; Pellicer-Sifres, V.; Boni, A. Exploring the Contribution of Grassroots Innovations to Justice: Using the Capability Approach to Normatively Address Bottom-Up Sustainable Transitions Practices. Sustainability 2020, 12, 3617. [CrossRef]

2. Díaz Orueta, F.; Lourés Seoane, M.L. Capítulo 4. Las grandes ciudades y la crisis de la democracia: Modalidades de articulación entre nuevas iniciativas sociales y gobiernos locales. In El momento De La Ciudadanía: Innovación Social y Gobernanza Urbana; Investigación y Debate; Catarata: Madrid, Spain, 2018; pp. 74-100. ISBN 978-84-9097-391-2.

3. Escobar, O.; Elstub, S. Introduction to the Handbook of Democratic Innovation and Governance: The field of democratic innovation. In Handbook of Democratic Innovation and Governance; Elstub, S., Escobar, O., Eds.; Edward Elgar Publishing: Cheltenham, UK; Northampton, MA, USA, 2019; pp. 11-31. ISBN 978-1-78643-385-5.

4. Moulaert, F.; MacCallum, D.; Mehmood, A.; Hamdouch, A. General Introduction: The Return of Social Innovation as a Scientific Concept and a Social Practice. In The International Handbook on Social Innovation. Collective Action, Social Learning and Transdisciplinary Research; Edward Elgar: Cheltenham, UK, 2013; pp. 1-6. ISBN 978-1-78254-559-0.

5. Moulaert, F.; MacCallum, D. Advanced Introduction to Social Innovation; Elgar Advanced Introductions Series; Edward Elgar Publishing: London, UK, 2019; ISBN 978-1-78536-037-4.

6. Oosterlynck, S.; Kazepov, Y.; Cools, P.; Barberis, E.; Wukovitsch, F.; Sarius, T.; Leubolt, B. The Butterfly and the Elephant: Local Social Innovation, the Welfare State and New Poverty Dynamics; Herman Deleeck Centre for Social Policy-University of Antwerp: Antwerp, Belgium, 2013.

7. Walliser, A. New Urban Activisms in Spain: Reclaiming Public Space in the Face of Crises. Policy Politics 2013, 41, 329-350. [CrossRef]

8. Puerari, E.; De Koning, J.I.J.C.; Von Wirth, T.; Karré, P.M.; Mulder, I.J.; Loorbach, D.A. Co-Creation Dynamics in Urban Living Labs. Sustainability 2018, 10, 1893. [CrossRef]

9. Bayırbă̆, M.K.; Davies, J.S.; Münch, S. Interrogating Urban Crisis: Cities in the Governance and Contestation of Austerity. Urban Stud. 2017, 54, 2023-2038. [CrossRef]

10. Martí-Costa, M.; Tomàs, M. Urban Governance in Spain: From Democratic Transition to Austerity Policies. Urban Stud. 2017, 54, 2107-2122. [CrossRef]

11. De la Fuente, R.; Medina-García, C. Innovación social en el Madrid contemporáneo: Influencia e institucionalización de los movimientos sociales en la redefinición de la gobernanza local. In Los Nuevos Retos de las Políticas Urbanas; Navarro, C.J., Ed.; Tirant lo Blanch: Valencia, Spain, 2021; pp. 31-42. ISBN 978-84-18155-65-9.

12. Russell, B. Beyond the Local Trap: New Municipalism and the Rise of the Fearless Cities. Antipode 2019, 51, 989-1010. [CrossRef]

13. Nyseth, T.; Hamdouch, A. The Transformative Power of Social Innovation in Urban Planning and Local Development. Urban Plan. 2019, 4, 1-6. [CrossRef]

14. De la Fuente, R.; Velasco González, M. Redefining Governance in the City: New Urban Activisms and Public Space in Madrid. Transgob Rep. Ser. 2016, 5, 1-20.

15. Stone, C.N. Regime Politics: Governing Atlanta 1946-1988; University Press of Kansas: Lawrence, KS, USA, 1989; ISBN 978-0-70060416-6.

16. Sørensen, E.; Torfing, J. Enhancing Collaborative Innovation in the Public Sector. Adm. Soc. 2011, 43, 842-868. [CrossRef]

17. Fung, A. Putting the Public Back into Governance: The Challenges of Citizen Participation and Its Future. Public Adm. Rev. 2015, 75, 513-522. [CrossRef]

18. Díaz Orueta, F. Regímenes Urbanos y Movimiento Ciudadano En Valencia. Cuad. Urbano 2010, 9, 275-294. [CrossRef]

19. Stone, C.N. Urban Regimes and the Capacity to Govern: A Political Economy Approach. J. Urban Aff. 1993, 15, 1-28. [CrossRef]

20. Pradel Miquel, M.; Garcia, M.; Eizaguirre, S. Chapter 11: Theorizing multi-level governance in social innovation dynamics. In The International Handbook on Social Innovation. Collective Action, Social Learning and Transdisciplinary Research; Edward Elgar: Cheltenham, UK, 2013; pp. 155-168. ISBN 978-1-78254-559-0.

21. Eizaguirre, S.; Pradel, M.; Terrones, A.; Martinez-Celorrio, X.; García, M. Multilevel Governance and Social Cohesion: Bringing Back Conflict in Citizenship Practices. Urban Stud. 2012, 49, 1999-2016. [CrossRef]

22. Jessop, B. Multi-level Governance and Multi-level Metagovernance: Changes in the European Union as Integral Moments in the Transformation and Reorientation of Contemporary Statehood. In Multi-Level Governance; Oxford University Press: Oxford, UK, 2004; ISBN 978-0-19-160096-8.

23. Kazepov, Y.; Colombo, F.; Sarius, T. The multi-scalar puzzle of social innovation. In Local Social Innovation to Combat Poverty and Exclusion: A Critical Appraisal; Bristol University Press: Bristol, UK, 2020; pp. 91-111. 
24. Moulaert, F.; MacCallum, D.; Mehmood, A.; Hamdouch, A. (Eds.) The International Handbook on Social Innovation; Edward Elgar: Cheltenham, UK, 2014; ISBN 978-1-84980-999-3.

25. Arampatzi, A. The Spatiality of Counter-Austerity Politics in Athens, Greece: Emergent 'Urban Solidarity Spaces'. Urban Stud. 2017, 54, 2155-2171. [CrossRef]

26. Parés, M.; Ospina, S.M.; Subirats, J. Social Innovation and Democratic Leadership: Communities and Social Change from Below; Edward Elgar Publishing: Cheltenham, UK, 2017; ISBN 978-1-78536-787-8.

27. García Cabeza, M.; Pradel Miquel, M.; Díaz Orueta, F. El Momento de la Ciudadanía: Innovación Social y Gobernanza Urbana; Investigación y Debate; Catarata: Madrid, Spain, 2018; ISBN 978-84-9097-391-2.

28. Holemans, D.; Van de Velde, K.; De Moor, T.; Kint, C. Quand Les Citoyens Prennent Les Choses En Main: Coup de Projecteur Sur Les Collectifs Citoyens Créés En 2015-2016; Fondation Roi Baudouin: Brussels, Belgium, 2018.

29. Eizaguirre, S.; Parés, M. Communities Making Social Change from below. Social Innovation and Democratic Leadership in Two Disenfranchised Neighbourhoods in Barcelona. Urban Res. Pract. 2018, 1-19. [CrossRef]

30. Moulaert, F.; MacCallum, D.; Van den Broeck, P.; Garcia, M. Bottom-Linked Governance and Socially Innovative Political Transformation. In Atlas of Social Innovation 2nd Volume: A World of New Practices; Oekom: München, Germany, 2019 ; p. 4. ISBN 978-3-96238-157-8.

31. Mulgan, G.; Pulford, L. Study on Social Innovation; European Union/The Young Foundation: London, UK, $2010 ;$ p. 127.

32. Murray, R.; Caulier-Grice, J.; Mulgan, G. The Open Book of Social Innovation; Social Innovator Series; The Young Foundation/NESTA: London, UK, 2010; ISBN 978-1-84875-071-5.

33. Moulaert, F.; Nussbaumer, J. Defining the Social Economy and Its Governance at the Neighbourhood Level: A Methodological Reflection. Urban Stud. 2005, 42, 2071-2088. [CrossRef]

34. Moulaert, F. Social innovation and community development: Concepts, theories and challenges. In Can Neighbourhoods Save the City? Community Development and Social Innovation; Routledge: Abingdon, UK, 2010; pp. 4-16. ISBN 978-0-203-84913-2.

35. Blanco, I. Analysing Urban Governance Networks: Bringing Regime Theory Back in. Environ. Plan. C Gov. Policy 2013, 31, $276-291$. [CrossRef]

36. Defourny, J.; Nyssens, M. Chapter 3: Social Innovation, Social Economy and Social Enterprise: What Can the European Debate Tell Us? In The International Handbook on Social Innovation. Collective Action, Social Learning and Transdisciplinary Research; Edward Elgar: Cheltenham, UK, 2013; pp. 40-52. ISBN 978-1-78254-559-0.

37. Moulaert, F. Social Innovation: Institutionally Embedded, Territorially (Re)produced. Chapter 1. In Social Innovation and Territorial Development; Ashgate: Farnham, UK, 2009; pp. 11-24. ISBN 978-0-7546-7233-3.

38. Mehmood, A.; Parra, C. Chapter 4: Social Innovation in an Unsustainable World. In The International Handbook on Social Innovation: Collective Action, Social Learning and Transdisciplinary Research; Edward Elgar: Cheltenham, UK, 2013 ; pp. 40-52. ISBN 978-1-78254-559-0.

39. Van Dyck, B.; Van den Broeck, P. Chapter 9: Social innovation: A territorial process. In The International Handbook on Social Innovation; Edward Elgar Publishing: Cheltenham, UK, 2013; pp. 131-141. ISBN 978-1-84980-999-3.

40. Fainstein, S.S. The Just City. Int. J. Urban Sci. 2014, 18, 1-18. [CrossRef]

41. Balboa, C.M. Urbanismo Colaborativo. Cuad. Investig. Urbanística 2017, 115, 3-100.

42. Van den Broeck, P.; Mehmood, A.; Paidakaki, A.; Parra, C. (Eds.) Social Innovation as Political Transformation: Thoughts for a Better World; Edward Elgar Publishing: Cheltenham, UK; Northampton, MA, USA, 2020; ISBN 978-1-78897-518-6.

43. MacCallum, D.; Moulaert, F.; Hillier, J.; Vicari Haddock, S. (Eds.) Social Innovation and Territorial Development; Ashgate: Farnham, UK, 2009; ISBN 978-0-7546-7233-3.

44. Nyseth, T.; Ringholm, T.; Agger, A. Innovative Forms of Citizen Participation at the Fringe of the Formal Planning System. Urban Plan. 2019, 4, 7-18. [CrossRef]

45. Moulaert, F.; Paidakaki, A.; Van den Broeck, P. Exploring the politico-institutional dimension of social innovation to repoliticize urban governance arrangements. In Social Innovation in Urban and Regional Research; Verlag der Österreichischen Akademie der Wissenschaften: Vienna, Austria, 2018; pp. 11-21.

46. Kunnen, N.; MacCallum, D.; Young, S. Research Strategies for Assets and Strengths Based Community Development. In The International Handbook on Social Innovation: Collective Action, Social Learning and Transdisciplinary Research; Edward Elgar Publishing: Cheltenham, UK, 2013; pp. 285-298. ISBN 978-1-78254-559-0.

47. González, S.; Healey, P. A Sociological Institutionalist Approach to the Study of Innovation in Governance Capacity. Urban Stud. 2005, 42, 2055-2069. [CrossRef]

48. Healey, P. Re-Enchanting Democracy as a Mode of Governance. Crit. Policy Stud. 2012, 6, 19-39. [CrossRef]

49. González, S.; Moulaert, F.; Martinelli, F. ALMOLIN How to analyse social innovation at the local level? In Can Neighbourhoods Save the City? Community Development and Social Innovation; Routledge: Abingdon, UK, 2010; pp. 49-67. ISBN 978-0-203-84913-2.

50. Lukesch, R.; Ludvig, A.; Slee, B.; Weiss, G.; Živojinović, I. Social Innovation, Societal Change, and the Role of Policies. Sustainability 2020, 12, 7407. [CrossRef]

51. Martinelli, F.; Morgan, K. From technological to social innovation: Rehabilitating the state and civil society in the development debate. In Social Innovation as Political Transformation: Thoughts for a Better World; Van den Broeck, P., Mehmood, A., Paidakaki, A., Parra, C., Eds.; 2019; pp. 30-37. ISBN 978-1-78897-518-6. 
52. Manganelli, A.; van den Broeck, P.; Moulaert, F. Socio-Political Dynamics of Alternative Food Networks: A Hybrid Governance Approach. Territ. Politics Gov. 2020, 8, 299-318. [CrossRef]

53. Paidakaki, A.; Moulaert, F.; Leinfelder, H.; Broeck, P.V. den Can Pro-Equity Hybrid Governance Shape an Egalitarian City? Lessons from Post-Katrina New Orleans. Territ. Politics Gov. 2020, 1-19. [CrossRef]

54. Martí, M.; Blanco, I.; Parés, M.; Subirats, J. Regeneración urbana y gobernanza. ¿Cómo evaluar la participación en una red de gobernanza? Tres perspectivas teóricas y un estudio de caso. In Participación, Políticas Públicas y Territorio: Aprotes Para la Construcción de una Perspectiva Integral; Rofman, A., Ed.; Ediciones UNGS: Buenos Aires, Argentina, 2016; pp. 27-52. ISBN 978987-630-228-9.

55. Jessop, B.; Sum, N.-L. Putting solidarity in its place in metagovernance. In Social Innovation as Political Transformation: Thoughts for a Better World; Van den Broeck, P., Mehmood, A., Paidakaki, A., Parra, C., Eds.; Edward Elgar Publishing: Cheltenham, UK; Northampton, MA, USA, 2020; pp. 90-96. ISBN 978-1-78897-518-6.

56. Sterling, J.S.; Moore, W.E. Weber's Analysis of Legal Rationalization: A Critique and Constructive Modification. Sociol. Forum 1987, 2, 67-89. [CrossRef]

57. Huxham, C. The Challenge of Collaborative Governance. Public Manag. Int. J. Res. Theory 2000, 2, 337-358. [CrossRef]

58. Huxham, C.; Vangen, S. Managing to Collaborate: The Theory and Practice of Collaborative Advantage; Routledge: Florence, SC, USA, 2005; ISBN 978-0-203-01016-7.

59. Osborne, S.P. The New Public Governance? Public Manag. Rev. 2006, 8, 377-387. [CrossRef]

60. Crosby, B.C.; Bryson, J.M. Integrative Leadership and the Creation and Maintenance of Cross-Sector Collaborations. Leadersh. Q. 2010, 21, 211-230. [CrossRef]

61. Políticas urbanas e innovación social. Entre la coproducción y la nueva institucionalidad. Criterios de significatividad. In Innovación Social y Políticas Urbanas en España; Subirats, J., Ed.; Icaria: Barcelona, Spain, 2015; pp. 95-112. ISBN 978-84-9888-681-8.

62. Parés, M. Repensar La Participación De La Ciudadania En El Mundo Local, 1st ed.; Bienestar y Ciudadanía; Diputació de Barcelona. Àrea de Presidència. Gabinet de Premsa i Comunicació: Barcelona, Spain, 2017.

63. Craps, M.; Vermeesch, I.; Dewulf, A.; Sips, K.; Termeer, K.; Bouwen, R. A Relational Approach to Leadership for Multi-Actor Governance. Adm. Sci. 2019, 9, 12. [CrossRef]

64. Elstub, S.; Escobar, O. (Eds.) Handbook of Democratic Innovation and Governance; Edward Elgar Publishing: Cheltenham, UK; Northampton, MA, USA, 2019; ISBN 978-1-78643-385-5.

65. de Souza Briggs, X. Democracy as Problem Solving: Civic Capacity in Communities Across the Globe; MIT Press: Cambridge, MA, USA, 2008; ISBN 978-0-262-26929-2.

66. Elstub, S.; Escobar, O. (Eds.) Defining and typologising democratic innovations. In Handbook of Democratic Innovation and Governance; Edward Elgar Publishing: Cheltenham, UK; Northampton, MA, USA, 2019; pp. 11-31. ISBN 978-1-78643-385-5.

67. Torfing, J.; Bøgh Andersen, L.; Greve, C.; Klausen, K.K. Public Governance Paradigms: Competing and Co-Existing; Policy, Administrative and Institutional Change Series; Edward Elgar Publishing: Cheltenham, UK, 2020; ISBN 978-1-78897-121-8.

68. Lévesque, B. Chapter 2: Social Innovation in Governance and Public Management Systems: Toward a New Paradigm? In The International Handbook on Social Innovation: Collective Action, Social Learning and Transdisciplinary Research; Edward Elgar: Cheltenham, UK, 2013; pp. 25-39. ISBN 978-1-78254-559-0.

69. Geissel, B. On the evaluation of participatory innovations-A preliminary framework. In Participatory Democratic Innovations in Europe: Improving the Quality of Democracy? Geissel, B., Joas, M., Eds.; Barbara Budrich Publishers: Leverkusen, Germany, 2013; pp. 8-31. ISBN 978-3-8474-0371-5.

70. Ansell, C.; Gash, A. Collaborative Governance in Theory and Practice. J. Public Adm. Res. Theory 2008, 18, 543-571. [CrossRef]

71. Blanco, I. Between Democratic Network Governance and Neoliberalism: A Regime-Theoretical Analysis of Collaboration in Barcelona. Cities 2015, 44, 123-130. [CrossRef]

72. O'Flynn, I. Democratic innovations and theories of democracy. In Handbook of Democratic Innovation and Governance; Elstub, S., Escobar, O., Eds.; Edward Elgar Publishing: Cheltenham, UK; Northampton, MA, USA, 2019; pp. 32-44. ISBN 978-1-78643-385-5.

73. McGuire, M.; Agranoff, R. The Limitations of Public Management Networks. Public Adm. 2011, 89, 265-284. [CrossRef]

74. Stone, C.N. Reflections on Regime Politics: From Governing Coalition to Urban Political Order. Urban Aff. Rev. 2015, 51, 101-137. [CrossRef]

75. Russo, A.P.; Scarnato, A. “Barcelona in Common”: A New Urban Regime for the 21st-Century Tourist City? J. Urban Aff. 2017, 40, 455-474. [CrossRef]

76. Tonkiss, F. Austerity Urbanism and the Makeshift City. City 2013, 17, 312-324. [CrossRef]

77. Yin, R.K. Case Study Research: Design and Methods, 5th ed.; Sage: Thousand Oaks, CA, USA, 2014; ISBN 978-1-4522-4256-9.

78. Flyvbjerg, B. Five Misunderstandings about Case-Study Research. Qual. Inq. 2006, 12, 219-245. [CrossRef]

79. Walliser, A.; de la Fuente, R. Los Nuevos Activismos Urbanos y la Institucionalidad del Cambio en Madrid. In Cultura Territorial e Innovación Social: ¿Hacia un Nuevo Modelo Metropolitano en Europa del Sur? Romero, J., Baron, N., Eds.; Desarrollo territorial. Estudios y documentos; Universitat de València: Valencia, Spain, 2018; pp. 95-114. ISBN 978-84-9134-290-8.

80. De la Fuente, R.; Velasco, M. La Política Urbana En Madrid: Un Relato Provisional. Geopolítica(S) 2012, 3. [CrossRef]

81. Díaz Orueta, F.; Lourés Seoane, M.L. Capítulo 7. Madrid: La ruptura de un modelo institucional local refractario a las nuevas iniciativas sociales contra la desigualdad. In El Momento de la Ciudadanía: Innovación Social y Gobernanza Urbana; Investigación y Debate; Catarata: Madrid, Spain, 2018; pp. 144-168. ISBN 978-84-9097-391-2. 
82. Fernández-Güell, J.M. Madrid: A Tale of an Ambitious City That Failed to Fulfill Its Global Vision. Disp Plan. Rev. $2014,50,6-15$. [CrossRef]

83. Walliser Martínez, A. Espacio público, innovación social y gobernanza local. In Los Nuevos Retos de las Políticas Urbanas; Navarro, C.J., Ed.; Tirant lo Blanch: Valencia, Spain, 2021; pp. 131-144. ISBN 978-84-18155-65-9.

84. Díaz Orueta, F.; Lourés Seoane, M.L.; Izaola Argüeso, A. Nuevos actores sociales, innovación social y políticas urbanas. Cambios en los modelos de gobernanza local. In Los Nuevos Retos de las Politicas Urbanas; Navarro, C.J., Ed.; Tirant lo Blanch: Valencia, Spain, 2021; pp. 17-30. ISBN 978-84-18155-65-9.

85. Velasco, M.; de la Fuente, R. Redefining Governance in the City: New Urban Activisms and Public Space in Madrid; TRANSGOB Report Series: Madrid, Spain, 2016.

86. Menor, L. Intervenciones culturales como innovación en espacios públicos urbanos. El caso de imagina Madrid. In Los Nuevos Retos de las Políticas Urbanas; Navarro, C.J., Ed.; Tirant lo Blanch: Valencia, Spain, 2021; pp. 145-155. ISBN 978-84-18155-65-9.

87. Rubio-Pueyo, V. Municipalism in Spain: From Barcelona to Madrid, and Beyond; Rosa Luxemburg Stiftung: New York, NY, USA, 2017.

88. Ahora Madrid Programa Político Ahora Madrid. 2015. Available online: https://ahoramadrid.org/ahora-madrid/programa/ (accessed on 8 June 2018).

89. Ayuntamiento de Madrid. Plan de Gobierno 2015-2019; Ayuntamiento de Madrid: Madrid, Spain, 2016.

90. Ayuntamiento de Madrid Reglamento Orgánico de Participación Ciudadana. Boletín Comunidad Madr. 2004, 147, 80-90.

91. Rondelez, P.; Medina-García, C. Limits of Municipalism. What Can We Learn from Operación Chamartín? Minim 2020. Available online: https:/ / minim-municipalism.org/magazine/limits-of-municipalism-what-can-we-learn-from-operacion-chamartin (accessed on 1 August 2020).

92. Ayuntamiento de Madrid Decide Madrid. Available online: https:/ / decide.madrid.es/ (accessed on 8 June 2018).

93. Swyngedouw, E. Governance Innovation and the Citizen: The Janus Face of Governance-beyond-the-State. Urban Stud. 2005, 42, 1991-2006. [CrossRef]

94. Gibson-Graham, J.K.; Roelvink, G. Social Innovation for Community Economies. In Social Innovation and Territorial Development; Ashgate: Farnham, UK, 2009; pp. 25-38. ISBN 978-0-7546-7233-3.

95. Ayuntamiento de Madrid. Manual de Funcionamiento de la Mesas de Participación Presencial Para la Selección de los Proyectos de Presupuestos Participativos 2018; Ayuntamiento de Madrid: Madrid, Spain, 2018.

96. Ayuntamiento de Madrid. CONSULCON18; Democratic Cities Congress: Madrid, Spain, 2018.

97. Ayuntamiento de Madrid El Ayuntamiento invitará a 30.000 Hogares a Participar en el Observatorio de la Ciudad. Available online: https: / / diario.madrid.es/blog/notas-de-prensa/el-ayuntamiento-invitara-a-30-000-hogares-a-participar-en-elobservatorio-de-la-ciudad/ (accessed on 19 May 2019).

98. Ayuntamiento de Madrid Ordenanza de Cooperación Público-Social del Ayuntamiento de Madrid. Boletín Comunidad Madr. 2018, $140,59-73$.

99. Ayuntamiento de Madrid Aprobada la Ordenanza de Cooperación Público-Social de la ciudad de Madrid. Available online: https:/ / diario.madrid.es/blog/notas-de-prensa/aprobada-la-ordenanza-de-cooperacion-publico-social-de-la-ciudadde-madrid/ (accessed on 11 June 2018).

100. Ayuntamiento de Madrid Reglamento Orgánico de Funcionamiento de los Foros Locales de los Distritos de Madrid. Boletín Comunidad Madr. 2017, 7, 242-255.

101. Ayuntamiento de Madrid. Dossier Fondo de Reequilibrio Territorial 2016; Ayuntamiento de Madrid: Madrid, Spain, 2016.

102. Ayuntamiento de Madrid. Dossier Fondo de Reequilibrio Territorial 2017; Ayuntamiento de Madrid: Madrid, Spain, 2017.

103. Ahora Madrid. Ahora Madrid Personal Interview with one of Ahora Madrid's District Councellors; Ahora Madrid: Madrid, Spain, 2019.

104. Ayuntamiento de Madrid Nace La Mesa De Rehabilitación. Available online: https://www.madrid.es/portales/munimadrid/es/ Inicio/Actualidad/Noticias /Nace-la-Mesa-de-Rehabilitacion/?vgnextfmt=default\&vgnextoid=d70aed9bfe300510VgnVCM2 000000c205a0aRCRD\&vgnextchannel=a12149fa40ec9410VgnVCM100000171f5a0aRCRD (accessed on 2 June 2019).

105. Ayuntamiento de Madrid Alimentando Otro Modelo De Ciudad. Ya Está Constituida La Mesa de Seguimiento Compuesta Por Diferentes Áreas Del Ayuntamiento De Madrid. Available online: https:/ /www.madrid.es/portales/munimadrid/es/Inicio/ Actualidad/Noticias / Alimentando-otro-modelo-de-ciudad/?vgnextfmt=default\&vgnextoid=1b4f38c001455510VgnVCM100 0001d4a900aRCRD\&vgnextchannel=a12149fa40ec9410VgnVCM100000171f5a0aRCRD (accessed on 11 November 2020).

106. Ayuntamiento de Madrid. Plan Madrid Recupera (MAD-RE) Estrategia de Regeneración Urbana: Tomo 1: Memoria; Ayuntamiento de Madrid: Madrid, Spain, 2018.

107. Ayuntamiento de Madrid Estrategia de Alimentación Saludable y Sostenible 2018-2020: Memoria de ejecución Mayo 2019; Ayuntamiento de Madrid: Madrid, Spain, 2019.

108. Ayuntamiento de Madrid Ordenanza de Movilidad Sostenible. Boletín Comunidad Madr. 2018, 253, $130-251$.

109. Ahora Madrid. Área de Economia y Hacienda Personal interview with representative from the Área de Economía y Hacienda de Madrid; Ahora Madrid: Madrid, Spain, 2018.

110. Ayuntamiento de Madrid. Estrategia Municipal de Economía Social y Solidaria del Ayuntamiento de Madrid 2018-25; Ayuntamiento de Madrid: Madrid, Spain, 2018.

111. Ayuntamiento de Madrid. Programa MICOS; Ayuntamiento de Madrid: Madrid, Spain, 2016.

112. Ayuntamiento de Madrid. Itinerarios Habitables: Bases Para La Intervención En El Espacio Público En Áreas de Regeneración Urbana Preferente; Ayuntamiento de Madrid: Madrid, Spain, 2016. 
113. Ayuntamiento de Madrid. Plan A de Calidad del aire y Cambio Climático; Ayuntamiento de Madrid: Madrid, Spain, 2017.

114. Ayuntamiento de Madrid. Plan de Impulso del Consumo Sostenible de la Ciudad de Madrid (PICS) 2016-2019; Ayuntamiento de Madrid: Madrid, Spain, 2017.

115. Ayuntamiento de Madrid Plan Anual Normativo Del Ayuntamiento de Madrid Para El Año 2020. Boletín Ayunt. Madr. 2019, 8536, 8-16.

116. Ayuntamiento de Madrid. Documento Para El Trámite de Consulta Pública Previa Sobre La Derogación Del Reglamento Orgánico Del Observatorio de La Ciudad; Ayuntamiento de Madrid: Madrid, Spain, 2019.

117. Ayuntamiento de Madrid. Resolución de la Dirección General de Participación Ciudadana Por La Que Se Inicia el Expediente de Declaración De La Inviabilidad Sobrevenida De 232 Proyectos De Presupuestos Participativos Relativos a Las Convocatorias De 2016, 2017, 2018 y 2019; Ayuntamiento de Madrid: Madrid, Spain, 2020.

118. Ayuntamiento de Madrid. Anteproyecto De Reglamento Orgánico De Los Consejos De Proximidad De Los Distritos De Madrid; Ayuntamiento de Madrid: Madrid, Spain, 2020.

119. Madrid Agroecológico Movimientos Por La Transición Ecológica y El Derecho a La Alimentación Nos Plantamos Ante El Ayuntamiento de Madrid. Available online: http:/ / madridagroecologico.org/movimientos-por-la-transicion-ecologica-y-elderecho-a-la-alimentacion-se-plantan-ante-el-ayuntamiento-de-madrid/ (accessed on 25 June 2020).

120. Ayuntamiento de Madrid La Mesa de Seguimiento del Pacto de Milán Reanuda Su Actividad Con Una Reunión Telemática. Available online: https: / diario.madrid.es/madridalimenta/la-mesa-de-seguimiento-del-pacto-de-milan-reanuda-su-actividadcon-una-reunion-telematica/ (accessed on 12 November 2020).

121. Ayuntamiento de Madrid Madrid participa en el IV Encuentro Anual De La Red De Ciudades Por La Agroecología. Available online: https: / / diario.madrid.es/madridalimenta / madrid-participa-en-el-iv-encuentro-anual-de-la-red-de-ciudades-por-laagroecologia/ (accessed on 12 November 2020).

122. Ayuntamiento de Madrid. Memoria Propuesta Para El Trámite de La Consulta Pública Previa Sobre La Propuesta de Derogación de La Ordenanza de Cooperación Público-Social, Para Su Integración Parcial En El Reglamento Orgánico de Participación Ciudadana Del Ayuntamiento de Madrid, Así Como Sobre La Modificación Del Mismo; Ayuntamiento de Madrid: Madrid, Spain, 2020.

123. Lorite, Á. Las redes de cuidados de Madrid niegan estar gestionadas por el Ayuntamiento. Salto Diario 2020. Available online: https://www.elsaltodiario.com/coronavirus/las-redes-de-cuidados-de-madrid-niegan-estar-gestionadas-por-elayuntamiento (accessed on 1 June 2020).

124. Martínez, G. La Despensa Solidaria de Lavapiés Reclama Un Local al Ayuntamiento de Madrid Para Seguir Ayudando a 3.000 Vecinos. Público 2020. Available online: https:/ / www.publico.es/sociedad/crisis-coronavirus-despensa-solidaria-lavapiesreclama-local-ayuntamiento-madrid-seguir-ayudando-3000-vecinos.html (accessed on 1 August 2020).

125. Redes de Cuidados Madrid Comunicado redes de cuidados de Madrid. Available online: https://madridenaccion.org/ comunicado-redes-de-cuidados-de-madrid/ (accessed on 12 November 2020).

126. SOLIVID Solivid/Recull iniciatives solidaries Covid19. Available online: https://www.solivid.org/?lang=es (accessed on 19 December 2020).

127. Gacetín Madrid El Ayuntamiento de Madrid pone en marcha el Plan de Huertos Solidarios. Available online: https:// gacetinmadrid.com/2020/05/20/el-ayuntamiento-de-madrid-pone-en-marcha-el-plan-de-huertos-solidarios / (accessed on 25 June 2020).

128. Ayuntamiento de Madrid Estrategia Urbana-Inicio. Available online: https:/ / estrategiaurbana.madrid.es/ (accessed on 13 July 2020).

129. Ayuntamiento de Madrid MADRID 360, La Estrategia Para Cumplir Con Los Objetivos De Calidad Del Aire De La Unión Europea. Available online: https://www.madrid.es/portales/munimadrid/es/Inicio/Actualidad/Noticias/MADRID-360-laestrategia-para-cumplir-con-los-objetivos-de-calidad-del-aire-de-la-Union-Europea/?vgnextfmt=default\&vgnextoid=3d6c1 609d818d610VgnVCM2000001f4a900aRCRD\&vgnextchannel=a12149fa40ec9410VgnVCM100000171f5a0aRCRD (accessed on 12 November 2020).

130. Brain, D. Reconstituting the Urban Commons: Public Space, Social Capital and the Project of Urbanism. Urban Plan. 2019, 4, 169-182. [CrossRef] 